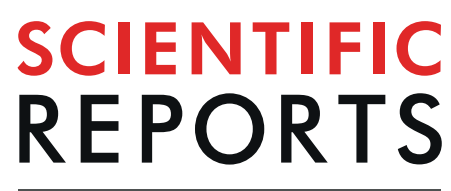

natureresearch

\title{
A novel phospho-modulatory mechanism contributes to the calcium-dependent regulation of T-type $\mathrm{Ca}^{2+}$ channels
}

\author{
Jean Chemin ${ }^{1,2^{*}}$, Tamara Timic Stamenic $\mathbb{C}^{3}$, Magalie Cazade ${ }^{1,2}$, Jodie Llinares ${ }^{1,2}$, \\ Iulia Blesneac ${ }^{1,2}$, Slobodan M. Todorovic ${ }^{3}$ \& Philippe Lory ${ }^{1,2}$
}

$\mathrm{Ca}_{\mathrm{v}} 3$ / T-type $\mathrm{Ca}^{2+}$ channels are dynamically regulated by intracellular $\mathrm{Ca}^{2+}$ ions, which inhibit $\mathrm{Ca}_{\mathrm{v}} 3$ availability. Here, we demonstrate that this inhibition becomes irreversible in the presence of nonhydrolysable ATP analogs, resulting in a strong hyperpolarizing shift in the steady-state inactivation of the residual $\mathrm{Ca}_{\mathrm{v}} 3$ current. Importantly, the effect of these ATP analogs was prevented in the presence of intracellular BAPTA. Additional findings obtained using intracellular dialysis of inorganic phosphate and alkaline phosphatase or $\mathrm{NaN}_{3}$ treatment further support the involvement of a phosphorylation mechanism. Contrasting with $\mathrm{Ca}_{v} 1$ and $\mathrm{Ca}_{v} 2 \mathrm{Ca}^{2+}$ channels, the $\mathrm{Ca}^{2+}$-dependent modulation of $\mathrm{Ca}_{\mathrm{v}} 3$ channels appears to be independent of calmodulin, calcineurin and endocytic pathways. Similar findings were obtained for the native T-type $\mathrm{Ca}^{2+}$ current recorded in rat thalamic neurons of the central medial nucleus. Overall, our data reveal a new $\mathrm{Ca}^{2+}$ sensitive phosphorylation-dependent mechanism regulating $\mathrm{Ca}_{\mathrm{v}} 3$ channels, with potentially important physiological implications for the multiple cell functions controlled by T-type $\mathrm{Ca}^{2+}$ channels.

Voltage-gated $\mathrm{Ca}^{2+}$ channels (VGCCs) are widely expressed in neurons, heart and muscles where they contribute to many critical physiological functions including cellular excitability but also muscle contraction, neurotransmitter release and gene expression ${ }^{1}$. An alteration in VGCC function leads to several diseases, including epilepsy, ataxia, chronic pain as well as cardiac pathologies ${ }^{1,2}$. Therefore, VGCC activity is tightly regulated by multiple intracellular pathways, including $\mathrm{Ca}^{2+}$ ions, which provide an important feedback control of $\mathrm{Ca}^{2+}$ homeostasis $^{3,4}$.

VGCCs are divided into three families: the L-type channels ( $\mathrm{Ca}_{\mathrm{v}} 1$ family); the neuronal N-, P/Q-, and R-type channels $\left(\mathrm{Ca}_{\mathrm{v}} 2\right.$ family); and the T-type channels $\left(\mathrm{Ca}_{\mathrm{v}} 3 \text { family }\right)^{5}$. The $\mathrm{Ca}_{\mathrm{v}} 3$ channels display unique electrophysiological features including a low-voltage-activated $\mathrm{Ca}^{2+}$ current, fast inactivation kinetics and a strong steady-state inactivation at physiological resting potentials ${ }^{6,7}$. These electrophysiological properties of T-type channels allow the generation of low-threshold spikes in neurons subsequent to transient membrane hyperpolarization ${ }^{6,7}$. Low-threshold spikes mediate rebound burst firing, which have important physiological implication, especially in thalamo-cortical circuit where T-type channels control transition between awake and sleep states ${ }^{6-9}$. T-type channels are also implicated in several neuronal disorders including epilepsy, chronic pain, autism, schizophrenia and cerebellar ataxia ${ }^{2,8,10-12}$. Consequently, the understanding of T-type channel regulation is of great physiological importance.

In contrast with $\mathrm{Ca}_{\mathrm{v}} 1$ and $\mathrm{Ca}_{\mathrm{v}} 2$ VGCCs, for which the regulation by intracellular $\mathrm{Ca}^{2+}$ has been extensively studied ${ }^{3,4,13,14}$, the regulation of $\mathrm{Ca}_{\mathrm{v}} 3$ channels by $\mathrm{Ca}^{2+}$ ions has been underappreciated until recently ${ }^{15-18}$. We have previously shown that the $\mathrm{Ca}_{\mathrm{v}} 3.3$ current (and to a lesser extend the $\mathrm{Ca}_{\mathrm{v}} 3.1$ current but not the $\mathrm{Ca}_{\mathrm{v}} 3.2$ current) is inhibited at a fast frequency of stimulation, providing an important feedback control ${ }^{15}$. This inhibition is associated with faster current inactivation kinetics and a negative shift in the steady-state inactivation of the $\mathrm{Ca}_{\mathrm{v}} 3.3$ current. Interestingly, these effects are observed when recording $\mathrm{Ca}_{\mathrm{v}} 3.3$ inward current but not $\mathrm{Ca}_{\mathrm{v}} 3.3$ outward current indicating that a role of a voltage-dependent inactivation is unlikely ${ }^{15}$. Furthermore the current inhibition is abolished in the presence of intracellular BAPTA but not EGTA, indicating the involvement of

${ }^{1}$ IGF, CNRS, INSERM, University of Montpellier, Montpellier, France. 'LabEx'Ion Channel Science and Therapeutics', 34094, Montpellier, France. ${ }^{3}$ Department of Anesthesiology, University of Colorado, Aurora, CO, 80045, USA. *email: jean.chemin@igf.cnrs.fr 
A
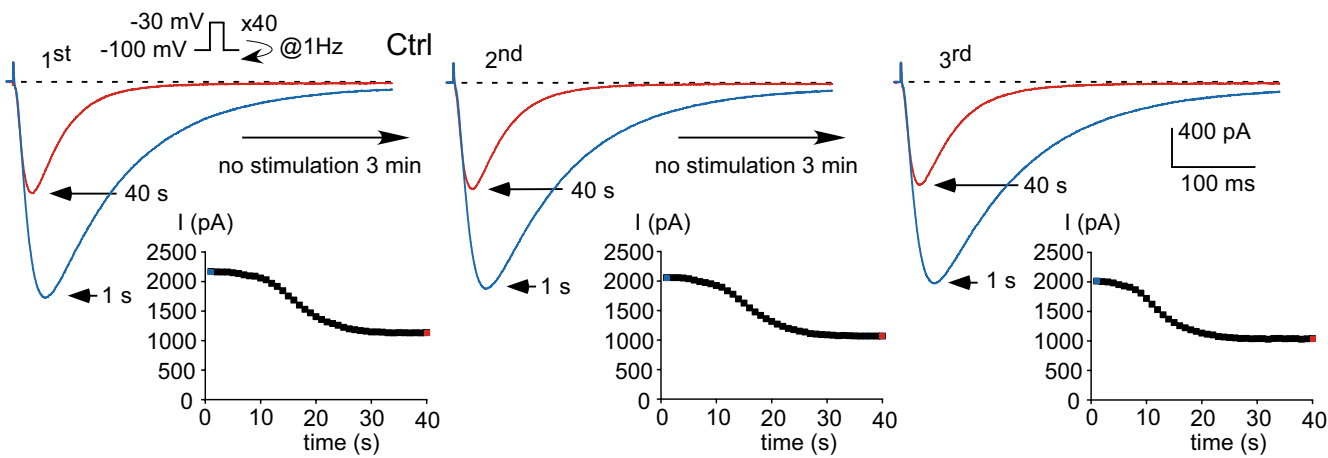

B
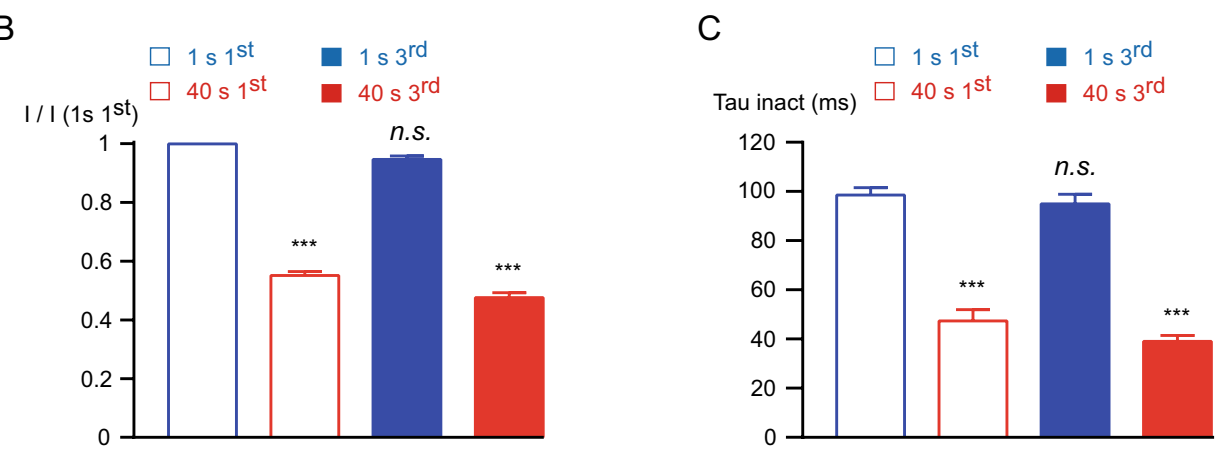

Figure 1. The $\mathrm{Ca}_{\mathrm{v}} 3.3$ current inhibition induced by stimulation at $1 \mathrm{~Hz}$ frequency (activity-dependent) is reversible and reproducible. (A) Typical examples of $\mathrm{Ca}_{\mathrm{v}} 3.3$ currents elicited by a test pulse stimulation at -30 $\mathrm{mV}(450 \mathrm{~ms}$ duration) applied at a frequency of $1 \mathrm{~Hz}$ from a holding potential $(\mathrm{HP})$ of $-100 \mathrm{mV}$. The traces obtained at the beginning of the stimulation ( $1 \mathrm{~s}$ ) and after $40 \mathrm{~s}$ stimulation are indicated in blue and red, respectively. Stopping the stimulation for 3 minutes allows the recovery of the $\mathrm{Ca}_{\mathrm{v}} 3.3$ current. The protocol was applied 3 times and the time course of the current amplitude is indicated as an inset. (B) Amplitude of the $\mathrm{Ca}_{\mathrm{v}} 3.3$ current at the beginning $(1 \mathrm{~s})$ and after $40 \mathrm{~s}$ obtained at the $1^{\mathrm{st}}$ and the $3^{\text {rd }}$ stimulation normalized to the initial current amplitude obtained at the beginning of the $1^{\text {st }}$ stimulation: $\mathrm{I}\left(1 \mathrm{~s} 1^{\text {st }}\right), \mathrm{n}=21$. (C) Inactivation kinetics of the $\mathrm{Ca}_{\mathrm{v}} 3.3$ current at the beginning of the stimulation $(1 \mathrm{~s})$ and after $40 \mathrm{~s}$ obtained for the $1^{\text {st }}$ and the $3^{\text {rd }}$ stimulation $(n=21)$. Asterisks indicate significant difference as compared to the initial current $\left(1 \mathrm{~s} 1^{\text {st }}\right)$ amplitude (B) and inactivation kinetics (C). (n.s.: non-significant).

submembrane $\mathrm{Ca}^{2+}$ ions. However, $\mathrm{Ca}^{2+}$ ions have no effect on the $\mathrm{Ca}_{\mathrm{v}} 3.3$ current recorded in cell-free inside-out patches indicating the necessity of an intracellular transduction pathway that takes place in the intact cells. For the $\mathrm{Ca}_{\mathrm{v}} 1$ and $\mathrm{Ca}_{\mathrm{v}} 2$ VGCCs, several studies have indicated that, depending of the amount of the $\mathrm{Ca}^{2+}$ entry, the $\mathrm{Ca}^{2+}$-dependent regulation of these channels mainly involves activation of calmodulin ${ }^{19-22}$ and calcineurin ${ }^{23,24}$ as well as $\mathrm{Ca}^{2+}$-dependent endocytosis of the channels ${ }^{21,25,26}$. We therefore investigated whether any of these $\mathrm{Ca}^{2+}$-dependent processes could be involved in the high frequency stimulation-induced inhibition of $\mathrm{Ca}_{\mathrm{v}} 3.3$ current or its recovery following termination of the stimulation. Our results demonstrate that this $\mathrm{Ca}_{\mathrm{v}} 3.3$ current modulation does not depend on calmodulin, calcineurin or endocytosis of the channels but is regulated by a phosphorylation-dependent process. We found that a $\mathrm{Ca}^{2+}$-dependent phosphorylation controls the availability of $\mathrm{Ca}_{\mathrm{v}} 3$ channels by adjusting the voltage-dependence of the steady-state inactivation curve. Similar findings were observed on native T-type channels expressed in the central medial nucleus of the thalamus, in which T-type channels mediate rebound burst firing ${ }^{27}$. Hence, our findings strongly suggest the involvement of a novel $\mathrm{Ca}^{2+} /$ phosphorylation-dependent transduction pathway that finely adjusts the T-type channel properties necessary for proper physiological function.

\section{Results}

At high frequency stimulation, the $\mathrm{Ca}_{\mathrm{v}} 3.3$ current displays a $\mathrm{Ca}^{2+}$-dependent inhibition that is dynamically regulated ${ }^{15}$. During stimulations applied at $1 \mathrm{~Hz}$ frequency, the $\mathrm{Ca}_{v} 3.3$ current decreased $\sim 45 \%$ from its initial value after 40 seconds $(p<0.001$, Fig. $1 \mathrm{~A}, \mathrm{~B})$ and this decrease was associated with faster inactivation kinetics $(p<0.001$, Fig. 1C). Stopping the stimulation for 3 minutes allowed a full recovery of $\mathrm{Ca}_{\mathrm{v}} 3.3$ current amplitude, after which $\mathrm{Ca}_{\mathrm{v}} 3.3$ current decrease at fast stimulation could be reproduced several times (Fig. $1 \mathrm{~A}, 2^{\text {nd }}$ and $3^{\text {rd }}$ ). Applying this protocol 3 times (Fig. 1A) allowed us to quantify both the current inhibition and its recovery after the $1^{\text {st }}$ and the $3^{\text {rd }}$ stimulation. Quantification of current inhibition and current recovery was calculated as the ratio of the current amplitude obtained at the $3^{\text {rd }}$ stimulation before and after the $1 \mathrm{~Hz}$ stimulation to the initial current amplitude obtained at the $1^{\text {st }}$ stimulation ( $1 \mathrm{~s}^{\text {st}}$; Fig. 1B). Taking advantage of the reversibility and reproducibility of the $\mathrm{Ca}^{2+}$-dependent inhibition of the $\mathrm{Ca}_{v} 3.3$ current, we investigated the mechanisms underlying current decrease as well as current recovery. 
A

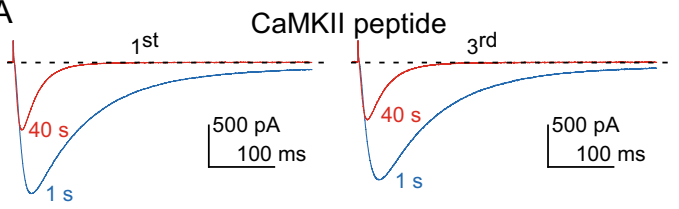

C

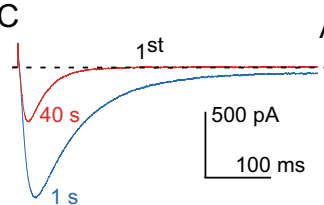

AIP

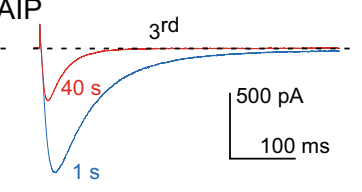

E

I/I (1s $\left.1^{\text {st }}\right)$

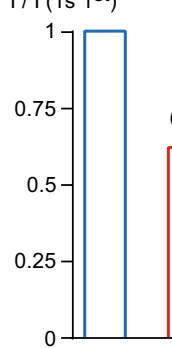

B

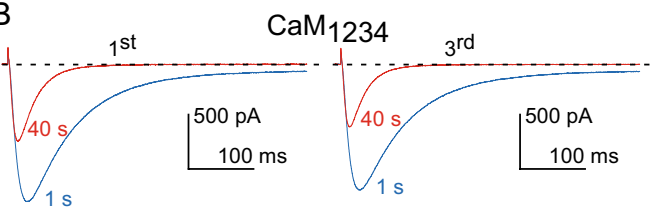

D

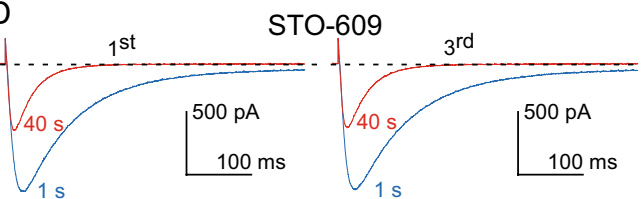

Figure 2. Calmodulin and CaMKII are not involved in the activity-dependent $\mathrm{Ca}_{\mathrm{v}} 3.3$ current inhibition. (A-D) Examples of $\mathrm{Ca}_{\mathrm{v}} 3.3$ currents elicited by the $1 \mathrm{~Hz}$ stimulation protocol during $40 \mathrm{~s}$ for the $1^{\text {st }}$ and the $3^{\text {rd }}$ stimulation in cells dialyzed with $100 \mu \mathrm{M}$ CaMKII peptide (A), in cells expressing CaM $_{1234}(\mathbf{B})$, in cells dialyzed with $100 \mu \mathrm{M}$ autocamtide-2-related inhibitory peptide, AIP (C), and in cells treated for 2 hours with $1 \mu \mathrm{M}$ STO609 (D). (E) Amplitude of the $\mathrm{Ca}_{\mathrm{v}} 3.3$ current at the beginning (1 s) and after $40 \mathrm{~s}$ obtained during the $1^{\text {st }}$ and the $3^{\text {rd }}$ stimulation normalized to the initial current amplitude obtained at the beginning of the $1^{\text {st }}$ stimulation I $\left(\begin{array}{lll}1 & s & 1^{\text {st }}\end{array}\right)$. Asterisks indicate significant difference in the current amplitude, as compared to the initial current amplitude. In addition, the current inhibition (red bars) and recovery (blue bars), as function of the treatment, was statistically compared to the respective control condition, as indicated. The number of cells tested is indicated into brackets. (n.s.: non-significant).

It has been demonstrated that a prolonged $\mathrm{Ca}^{2+}$ entry induces an internalization of the L-type channels via endocytosis, possibly leading to degradation in the lysosome $e^{21,25,26}$. We tested whether this pathway was implicated in the inhibition of $\mathrm{Ca}_{\mathrm{v}} 3.3$ current during fast stimulation (Supplementary Fig. 1). Endocytosis was disrupted by expressing a dominant negative mutant of dynamin 1 (Dyn 1 K44A), a GTPase required for the formation of endocytic vesicles from the plasma membrane and implicated in the endocytosis of the L-type channel $^{25,28}$. Expression of the Dyn 1 K44A mutant (Supplementary Fig. 1B) did not alter the inhibition of the $\mathrm{Ca}_{\mathrm{v}} 3.3$ current during fast stimulation $(\sim 45 \%, p<0.001$, red bars in Supplementary Fig. $1 \mathrm{E})$ as compared to WT dynamin or the control condition $\left(p>0.05\right.$, Supplementary Fig. 1A,E). In addition, the recovery of the $\mathrm{Ca}_{\mathrm{v}} 3.3$ current was not different in cells expressing the Dyn 1 K44A mutant (blue bars in Supplementary Fig. 1E) as compared to WT dynamin or the control condition $(p>0.05$, Supplementary Fig. 1A,E). Similar findings were obtained after expression of the adaptor protein 2 (AP-2), a central player in clathrin-mediated endocytosis ${ }^{29}$, which did not modify current inhibition $(\sim 45 \%, p<0.01)$ or its recovery (Supplementary Fig. 1C,E), as compared to the control condition ( $p>0.05$, Supplementary Fig. 1E). In addition, we have treated the cells with the lysosomal inhibitor bafilomycin ( $100 \mathrm{nM}, 3-5$ hours), using the same protocol as described for L-type channels ${ }^{26}$. We found that bafilomycin did not affect $\mathrm{Ca}_{\mathrm{v}} 3.3$ current inhibition at a high frequency of stimulation, nor its recovery (Supplementary Fig. 1D,E). The analysis of the $\mathrm{Ca}_{\mathrm{v}} 3.3$ current also indicated no significant effect of dynamin K44A, AP2 or bafilomycin treatment on current inactivation kinetics at the beginning as well as at the end of the fast stimulation protocol, as compared to the respective control condition $(p>0.05, \mathrm{n}=5-6)$.

Calmodulin (CaM) is important for the modulation of the L-type current ${ }^{19-22}$ and has emerged recently as a modulator of T-type channels, including $\mathrm{Ca}_{\mathrm{v}} 3 \cdot 3^{16-18}$. To investigate this pathway we first used a CaMKII peptide (100 $\mu$ M CaMKII 290-309) that binds CaM and inhibits its function and additional calmodulin-requiring enzymes. Dialysis of this peptide did not modify the $\mathrm{Ca}_{\mathrm{v}} 3.3$ current inhibition at $1 \mathrm{~Hz}$ frequency of stimulation, nor its recovery ( $p>0.05$, as compared to the control condition, Fig. $2 \mathrm{~A}, \mathrm{E})$. We next used a CaM mutant, $\mathrm{CaM}_{1234}$, which is unable to bind $\mathrm{Ca}^{2+}$ and was previously used to demonstrate the CaM regulation of the L-type channel ${ }^{19,20}$. Expression of this mutant was also without significant effect on $\mathrm{Ca}_{v} 3.3$ modulation (Fig. 2B,E), indicating that $\mathrm{CaM}$ was not involved in the decrease of $\mathrm{Ca}_{\mathrm{v}} 3.3$ current induced by stimulation at a high frequency or in its recovery. Similar results were obtained using the CaMKII inhibitory peptide (autocamtide-2-related inhibitory peptide, AIP, $100 \mu \mathrm{M}$ intrapipette) and STO-609, a CaMKK inhibitor ( $1 \mu \mathrm{M}$ incubation for 2 hours; Fig. 2C-E). In addition, the current inactivation kinetics at the beginning and at the end of the fast stimulation protocol were not significantly modified by CaMKII and AIP peptides or $\mathrm{CaM}_{1234}$ and STO-609, as compared to 
A

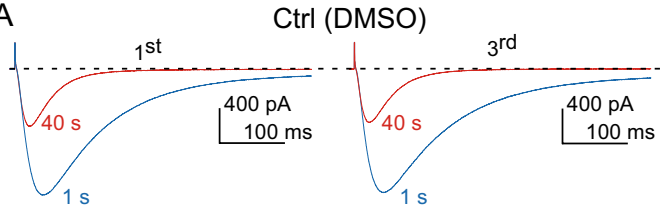

B

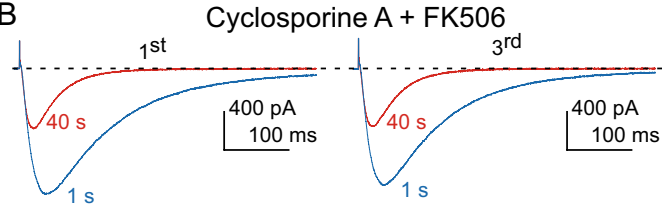

C

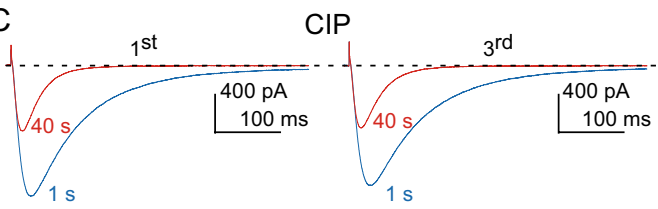

D

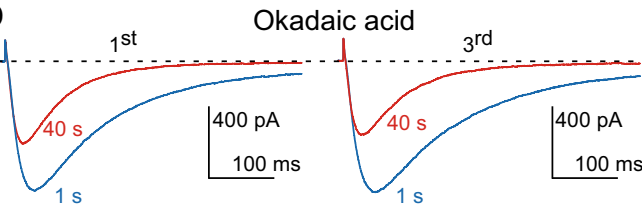

$\mathrm{E}$

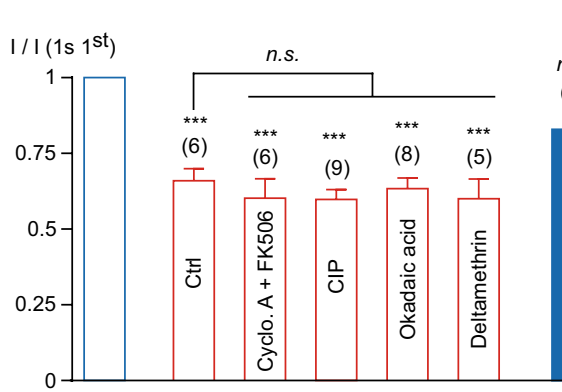

n.s.

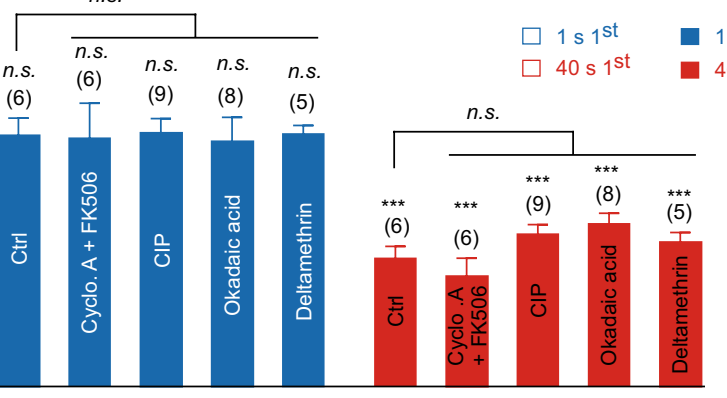

Figure 3. Calcineurin and okadaic acid sensitive phosphatases are not involved in the activity-dependent $\mathrm{Ca}_{\mathrm{v}} 3.3$ current inhibition. (A-D) Examples of $\mathrm{Ca}_{\mathrm{v}} 3.3$ currents elicited by the $1 \mathrm{~Hz}$ stimulation protocol during $40 \mathrm{~s}$ for the $1^{\text {st }}$ and the $3^{\text {rd }}$ stimulation in the control condition (A), in the presence of $10 \mu \mathrm{M}$ cyclosporin $\mathrm{A}$ and $10 \mu \mathrm{M}$ FK506 (B), in the presence of $100 \mu \mathrm{M}$ calcineurin inhibitory peptide (CIP) $($ C), and in the presence of $1 \mu \mathrm{M}$ okadaic acid (D). (E) Amplitude of the $\mathrm{Ca}_{\mathrm{v}} 3.3$ current at the beginning $(1 \mathrm{~s})$ and after $40 \mathrm{~s}$ obtained at the $1^{\text {st }}$ and the $3^{\text {rd }}$ stimulation normalized to the initial current amplitude I $\left(1 \mathrm{~s}{ }^{\text {st }}\right)$. Asterisks indicate significant difference in the current amplitude, as compared to the initial current amplitude. In addition, the current inhibition (red bars) and recovery (blue bars), as function of the treatment, was statistically compared to the respective control condition, as indicated. The number of cells tested is indicated into brackets. (n.s.: nonsignificant).

the respective control condition $(p>0.05, \mathrm{n}=5-8)$. However, we found that $\mathrm{CaM}_{1234}$ expression induced a negative shift $\sim 5.5 \mathrm{mV}$ in the steady-state inactivation of the $\mathrm{Ca}_{\mathrm{v}} 3.3$ current $(\mathrm{n}=8, p<0.005)$ compared to the control condition $(\mathrm{n}=5)$, as recently reported for the $\mathrm{Ca}_{\mathrm{v}} 3.2$ current $^{17}$.

It was also demonstrated that during $1 \mathrm{~Hz}$ frequency stimulation, the L-type current decreases similarly to the $\mathrm{Ca}_{\mathrm{v}} 3.3$ current and that this effect is mediated in part by calcineurin ${ }^{23,24}$. We have therefore tested whether this pathway was implicated in the $\mathrm{Ca}_{\mathrm{v}} 3.3$ current decrease. Cells were treated with a combination of cyclosporin A and FK506 (10 $\mu \mathrm{M}$ each) before patch-clamp experiments, a treatment that prevents the decrease and the calcium-dependent inactivation (CDI) of the L-type current ${ }^{23,24}$. We found that $1-2$ hours incubation with cyclosporin A and FK506 did not affect the decrease of the $\mathrm{Ca}_{\mathrm{v}} 3.3$ current, nor its recovery, as compared to vehicle (DMSO)-treated cells ( $p>0.05$, Fig. 3A,B,E). Similarly, inclusion of the calcineurin inhibitory peptide (CIP, $100 \mu \mathrm{M}$ in the patch pipette), which also prevents L-type current decrease and CDI ${ }^{23,24}$, did not affect the $\mathrm{Ca}_{\mathrm{v}} 3.3$ current modulation (Fig. 3C,E). We also found that both inhibition and recovery of the $\mathrm{Ca}_{\mathrm{v}} 3.3$ current were unaffected by okadaic acid ( $100 \mathrm{nM}$ overnight incubation and $1 \mu \mathrm{M}$ in the patch pipette) or by deltamethrin $(10 \mu \mathrm{M}$ in the patch pipette) (Fig. 3D,E). In addition, none of the compounds tested modified the current inactivation kinetics at the beginning and at the end of the fast stimulation protocol $(p>0.05$, as compared to the control condition, $\mathrm{n}=5-9)$. Similarly, no significant change on the steady-state inactivation of the $\mathrm{Ca}_{\mathrm{v}} 3.3$ current was observed ( $p>0.05$, as compared to the control condition, $n=7-14$ ). Overall, these findings strongly suggest that neither endocytosis nor CaM-dependent pathways nor calcineurin play a significant role in the $\mathrm{Ca}_{\mathrm{v}} 3.3$ current modulation at a high frequency of stimulation, which therefore requires different molecular mechanisms than those previously described for the L-type channel.

In order to investigate further the role of a phosphorylation mechanism in $\mathrm{Ca}_{\mathrm{v}} 3.3$ current modulation, we used inorganic phosphate to compete with phosphatase activities ${ }^{30,31}$. Inorganic phosphate $\left(\mathrm{Pi}, 10 \mathrm{mM} \mathrm{KH}_{2} \mathrm{PO}_{4}\right)$ was applied via the patch pipette 10 minutes before stimulation of the $\mathrm{Ca}_{\mathrm{v}} 3.3$ current. In the presence of intracellular Pi, fast stimulation induced a slight current decrease $\sim 20 \%(p<0.05$, Fig. 4B,C) whereas the current decrease was $\sim 45 \%$ in the control condition $(15 \mathrm{mM} \mathrm{KCl}$ in the patch pipette, $p<0.001$, Fig. $4 \mathrm{~A}, \mathrm{~B})$. In average, the current decrease in the presence of Pi was $\sim 35 \%$ less than the control value at the $3^{\text {rd }}$ stimulation $(p<0.01$; Fig. $4 \mathrm{C})$, whereas there was a slight but not significant increase in current recovery (Fig. 4C). In addition, during the stimulation at $1 \mathrm{~Hz}$ frequency, the acceleration in the inactivation kinetics was less pronounced in the presence of intracellular Pi as compared to the control condition ( $p<0.05$, Fig. 4D). It should be noted that in addition to competing with phosphatase activities, $\mathrm{KH}_{2} \mathrm{PO}_{4}$ may bind $\mathrm{Ca}^{2+}$ and therefore may act as a Ca ${ }^{2+}$ buffer. However, 
A

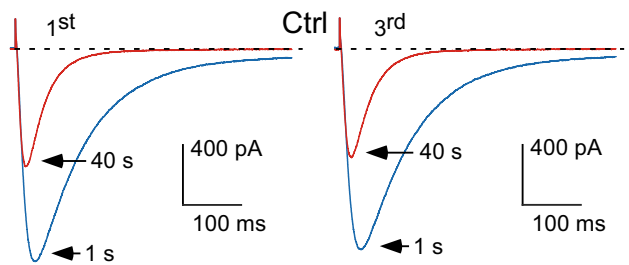

C

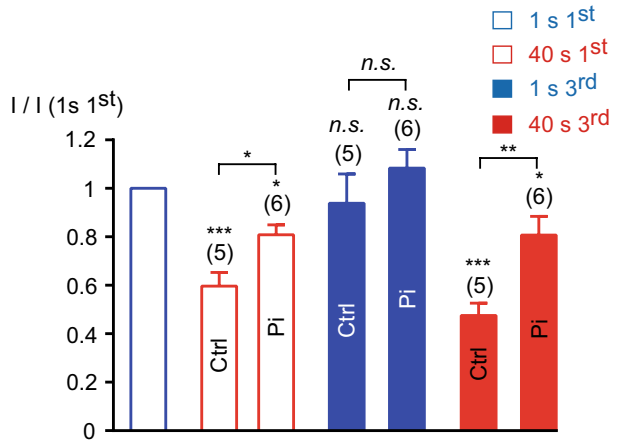

B

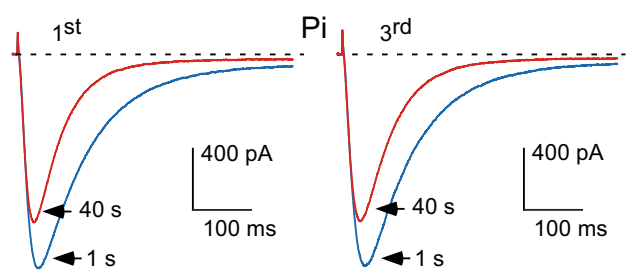

D

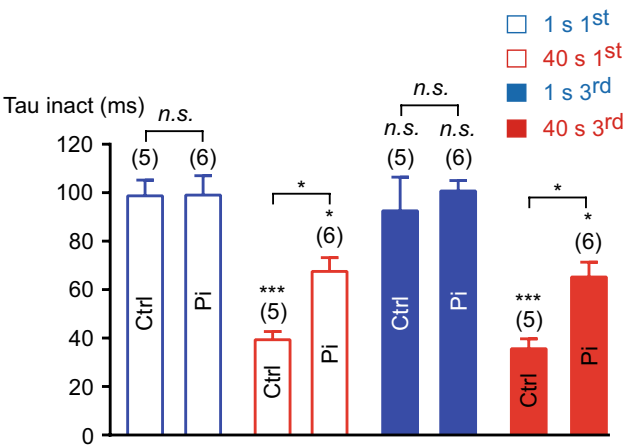

Figure 4. The activity-dependent $\mathrm{Ca}_{\mathrm{v}} 3.3$ current inhibition is reduced in the presence of inorganic phosphate (Pi). (A,B) Examples of $\mathrm{Ca}_{v} 3.3$ currents elicited by the $1 \mathrm{~Hz}$ stimulation protocol during $40 \mathrm{~s}$ for the $1^{\text {st }}$ and the $3^{\text {rd }}$ stimulation in cells dialyzed with $15 \mathrm{mM} \mathrm{KCl}, \mathrm{Ctrl}(\mathbf{A})$, and in cells dialyzed with $10 \mathrm{mM} \mathrm{KH}_{2} \mathrm{PO}_{4}, \mathrm{Pi}(\mathbf{B})$. (C) Amplitude of the Ca $\mathrm{C}_{\mathrm{v}} 3.3$ current at the beginning $(1 \mathrm{~s})$ and after $40 \mathrm{~s}$ obtained at the $1^{\text {st }}$ and the $3^{\text {rd }}$ stimulation normalized to the initial current amplitude I $\left(1 \mathrm{~s} 1^{\text {st }}\right)$. (D) Inactivation kinetics of the $\mathrm{Ca}_{\mathrm{v}} 3.3$ current at the beginning of the stimulation $(1 \mathrm{~s})$ and after $40 \mathrm{~s}$ stimulation obtained for the $1^{\text {st }}$ and the $3^{\text {rd }}$ stimulation. Asterisks indicate significant difference in the current amplitude $(\mathbf{C})$ and inactivation kinetics $(\mathbf{D})$, as compared to the initial current. In addition, variation in the current amplitude $(\mathbf{C})$ and in inactivation kinetics $(\mathbf{D})$ as function of the Pi treatment was statistically compared to the respective control condition, as indicated. The number of cells tested is indicated into brackets. (n.s.: non-significant).

we observed a similar decrease in $\mathrm{Ca}_{v} 3.3$ current in the cells dialyzed with an intracellular solution containing $20 \mathrm{mM}$ EGTA, as compared to our standard recording condition using $10 \mathrm{mM} \mathrm{EGTA}(p>0.5, \mathrm{n}=17)$, suggesting that the Pi effect does not rely on its $\mathrm{Ca}^{2+}$ buffer property. Moreover, these results suggest that a $\mathrm{Ca}^{2+}$-driven phosphatase might be responsible for the current decrease (see schematic representation in Supplementary Fig. 7). In agreement with the involvement of a phosphorylation mechanism, inclusion of recombinant alkaline phosphatase $(\mathrm{AP}, 100 \mathrm{U} / \mathrm{ml})$ in the patch pipette ${ }^{32}$ "mimicked" the inhibition of the $\mathrm{Ca}_{v} 3.3$ current at $1 \mathrm{~Hz}$ frequency stimulation (Supplementary Fig. 2A,B) and induced an acceleration in the current inactivation kinetics (Supplementary Fig. $2 \mathrm{~A}-\mathrm{C}$ ). Importantly, the remaining current after AP treatment was stable during the $1 \mathrm{~Hz}$ frequency stimulation protocol (Supplementary Fig. $2 \mathrm{~A}, \mathrm{~B}$ ). In addition, the steady-state inactivation of the $\mathrm{Ca}_{\mathrm{v}} 3.3$ current was largely shifted towards negative potentials after AP dialysis ( $25 \mathrm{mV}, p<0.001$; Supplementary Fig. 2D).

Considering that current inhibition could result from a phosphatase activity, we investigated whether a putative kinase activity might be implicated in current recovery (see schematic representation in Supplementary Fig. 7). To this purpose, the cells were incubated in the presence of $10 \mathrm{mM}$ sodium azide $\left(\mathrm{NaN}_{3}\right)$, which inhibits mitochondrial function ${ }^{33}$ and thereby results in a depletion of intracellular ATP (Fig. 5A,B). In the presence of $\mathrm{NaN}_{3}$ (and in the absence of ATP in the patch pipette), the $1 \mathrm{~Hz}$ stimulation induced a strong inhibition of the $\mathrm{Ca}_{\mathrm{v}} 3.3$ current $(\sim 70 \%, p<0.001$, Fig. $5 \mathrm{C})$, which is significantly larger than that observed in the control condition $\left(p<0.001\right.$, Fig. 5 C). Interestingly the recovery of the current at the $3^{\text {rd }}$ stimulation was completely abolished after $\mathrm{NaN}_{3}$ treatment and the residual current displayed fast inactivation kinetics $(p<0.001$, Fig. 5 C,D), suggesting that the recovery of the $\mathrm{Ca}_{v} 3.3$ current relies on an ATP-dependent mechanism. We therefore investigated whether the hydrolysis of the phosphate group from ATP is needed for current recovery. To this end we tested the effect of non-hydrolysable ATP analogs (Fig. 6). When intracellular ATP in the patch pipette was replaced by AMP-PCP, the inhibition of the $\mathrm{Ca}_{\mathrm{v}} 3.3$ current $(\sim 55 \%, p<0.001)$ at $1 \mathrm{~Hz}$ frequency stimulation was not significantly modified as compared to the control condition $(p>0.05$, Fig. $6 \mathrm{~A}, \mathrm{~B}, \mathrm{E})$, but the recovery of the $\mathrm{Ca}_{v} 3.3$ current was completely abolished $(p<0.001$; Fig. 6A,B,E). Similar findings were observed using another non-hydrolysable ATP analog, AMP-PNP, which completely abolished the recovery of the $\mathrm{Ca}_{\mathrm{v}} 3.3$ current $(p<0.001$; Fig. $6 \mathrm{C}, \mathrm{E})$ but did not modify current inhibition as compared to the control condition $(p>0.05$, Fig. $6 \mathrm{E})$. In the presence of AMP-PCP or AMP-PNP, the remaining current after stimulation at high frequency displayed fast inactivation kinetics $(p<0.001$, Fig. 6F). Because the depression of the current recovery may represent a spontaneous loss of channel activity (rundown) in the absence of intracellular ATP, we investigated the effect of AMP-PCP on the maintenance of $\mathrm{Ca}_{\mathrm{v}} 3.3$ current. To this purpose, $\mathrm{Ca}_{\mathrm{v}} 3.3$ currents were recorded during 30 minutes at a low frequency of stimulation (one stimulation each $180 \mathrm{~s} / 0.0055 \mathrm{~Hz}$ ) in the presence of intracellular ATP or intracellular AMP-PCP (Supplementary Fig. 3). At this low frequency of stimulation, there was no significant difference in $\mathrm{Ca}_{v} 3.3$ current rundown between control and AMP-PCP dialyzed cells (Supplementary Fig. 3A). On average 

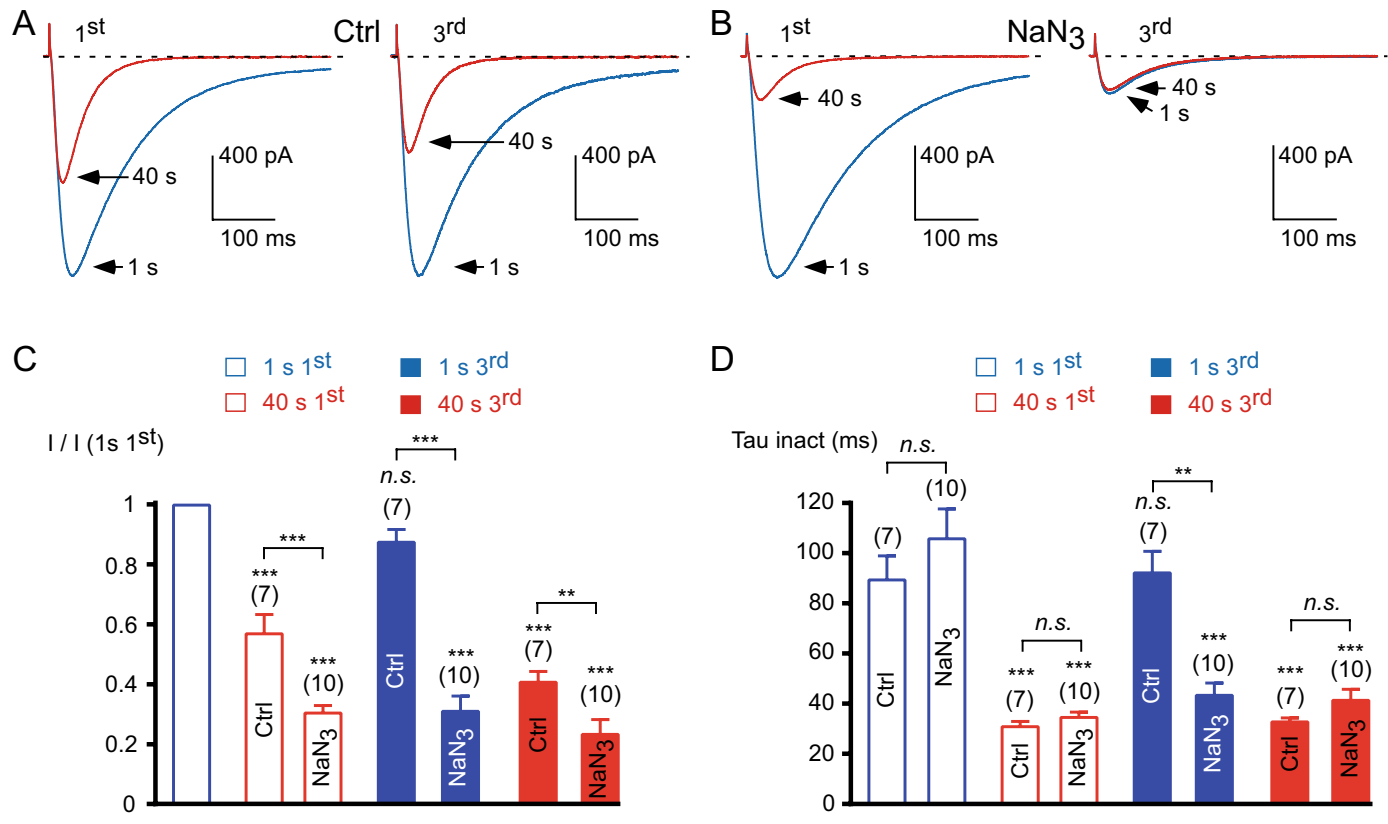

Figure 5. The recovery of the $\mathrm{Ca}_{\mathrm{v}} 3.3$ current is abolished in the presence of sodium azide. $(\mathbf{A}, \mathbf{B})$ Examples of $\mathrm{Ca}_{\mathrm{v}} 3.3$ currents elicited by the $1 \mathrm{~Hz}$ stimulation protocol during $40 \mathrm{~s}$ for the $1^{\text {st }}$ and the $3^{\text {rd }}$ stimulation in the control condition, $\mathrm{Ctrl}(\mathbf{A})$, and in cells treated with sodium azide, $\mathrm{NaN}_{3} 10 \mathrm{mM}$ for 2 hours (B). (C) Amplitude of the $\mathrm{Ca}_{\mathrm{v}} 3.3$ current at the beginning $(1 \mathrm{~s})$ and after $40 \mathrm{~s}$ obtained at the $1^{\mathrm{st}}$ and the $3^{\text {rd }}$ stimulation normalized to the initial current amplitude I $\left(1 \mathrm{~s} 1^{\text {st }}\right)$. (D) Inactivation kinetics of the $\mathrm{Ca}_{\mathrm{v}} 3.3$ current at the beginning of the stimulation ( $1 \mathrm{~s}$ ) and after $40 \mathrm{~s}$ stimulation obtained for the $1^{\text {st }}$ and the $3^{\text {rd }}$ stimulation. Asterisks indicate significant difference in the current amplitude $(\mathbf{C})$ and inactivation kinetics $(\mathbf{D})$, as compared to the initial current. In addition, variation in the current amplitude (C) and in inactivation kinetics (D) as function of the $\mathrm{NaN}_{3}$ treatment was statistically compared to the respective control condition, as indicated. The number of cells tested is indicated into brackets. (n.s.: non-significant).

channel activity was $94 \pm 6 \%(n=6)$ and $89 \pm 6 \%(n=6)$ of the initial value after 30 minutes of dialysis with $3 \mathrm{mM}$ intracellular ATP and with $3 \mathrm{mM}$ intracellular AMP-PCP, respectively. Thus, the decrease in $\mathrm{Ca}_{\mathrm{v}} 3.3$ current recovery was not due to faster rundown of the current but to ATP dependency of current recovery from $1 \mathrm{~Hz}$ frequency stimulation. Accordingly, after 30 minutes of dialysis, the application of the $1 \mathrm{~Hz}$ stimulation protocol induced a decrease in the $\mathrm{Ca}_{\mathrm{v}} 3.3$ current, which was irreversible in AMP-PCP dialyzed cells $(p<0.001$, Supplementary Fig. 3A). Importantly, in the presence of intracellular BAPTA (instead EGTA), which prevents a localized increase in submembrane $\mathrm{Ca}^{2+}$ and the $\mathrm{Ca}^{2+}$-dependent inhibition of the $\mathrm{Ca}_{\mathrm{v}} 3.3$ current ${ }^{15}$, we found that AMP-PCP did not produce current inhibition ( $p>0.05$, Fig. $6 \mathrm{D}-\mathrm{F}$ ) strongly indicating that the effect of non-hydrolysable ATP analogs relies on a $\mathrm{Ca}^{2+}$-dependent phosphorylation mechanism. It should be noted however, that $\mathrm{NaN}_{3}$ and non-hydrolysable ATP analogs may also interfere with mitochondrial function and could lead to an irreversible oxidative stress that may underlie the $\mathrm{Ca}_{\mathrm{v}} 3.3$ current inhibition observed at fast frequency of stimulation. In order to investigate the potential role of the redox status in the current inhibition, the cells were dialyzed with an intracellular medium containing $1 \mathrm{mM}$ dithiothreitol (DTT). After dialysis of DTT, the $1 \mathrm{~Hz}$ stimulation protocol induced inhibition of $\mathrm{Ca}_{v} 3.3$ current amplitude $(\sim 40 \%, p<0.001$, Supplementary Fig. 4B,C) that was associated with an acceleration of current inactivation kinetics ( $p<0.001$, Supplementary Fig. 4D). These effects were not different to those observed in the control condition ( $p>0.05$, Supplementary Fig. 4C,D). Similarly, current recovery was unaffected (Supplementary Fig. 4C), suggesting that current modulation does not depend on the redox status of the $\mathrm{Ca}_{\mathrm{v}} 3.3$ channel. We noted however that in the presence of DTT, the inactivation kinetics were slower at the beginning of the $1^{\text {st }}$ stimulation as compared to the control condition $(p<0.05, \mathrm{n}=7)$ but this effect was not significant at the $3^{\text {rd }}$ stimulation (Supplementary Fig. 4D).

Several pathways regulating $\mathrm{Ca}_{\mathrm{v}} 3$ current were identified, including $\mathrm{PKA}^{34-36}, \mathrm{PKC}^{35,37,38}$, Rho-associated kinase ${ }^{39}$, phospholipase $\mathrm{C}\left(\mathrm{PLC}^{40}\right)$, and $\mathrm{G} \beta \gamma^{36,41}$. We have tested whether these pathways could be implicated in the $\mathrm{Ca}_{\mathrm{v}} 3.3$ modulation at high frequency of stimulation using dibutyryl-cAMP (db-cAMP, a PKA activator), phorbol myristate acetate (PMA, a PKC activator), chelerythrine and bisindolylmaleimide IX (BIM IX, both PKC inhibitors), fasudil (a Rho-associated kinase inhibitor), U73122 and edelfosine (both PLC inhibitors) and pertussis toxin (PTX) or expression of the $\beta A R K-C t$ (both inhibiting G $\beta \gamma$ ). In the presence of these compounds, the inhibition $(\sim 50 \%, p<0.01$, Supplementary Fig. $5 \mathrm{~A})$ of the $\mathrm{Ca}_{\mathrm{v}} 3.3$ current was not different to that observed in the control condition ( $p>0.05$, Supplementary Fig. 5A). Importantly, these inhibitors did not modify the recovery of the $\mathrm{Ca}_{\mathrm{v}} 3.3$ current as compared to the control condition ( $p>0.05$, Supplementary Fig. 5B). Similarly, the inhibition of PI3K and PI4K with wortmannin or the inhibition of SERCA ${ }^{42}$ with cyclopiazonic acid (CPA) was without effect on both inhibition and recovery of the $\mathrm{Ca}_{\mathrm{v}} 3.3$ current $(p>0.05$ as compared to the control condition, Supplementary Fig. 5A,B). Collectively, these results indicate that the $\mathrm{Ca}_{\mathrm{v}} 3.3$ current modulation at high 

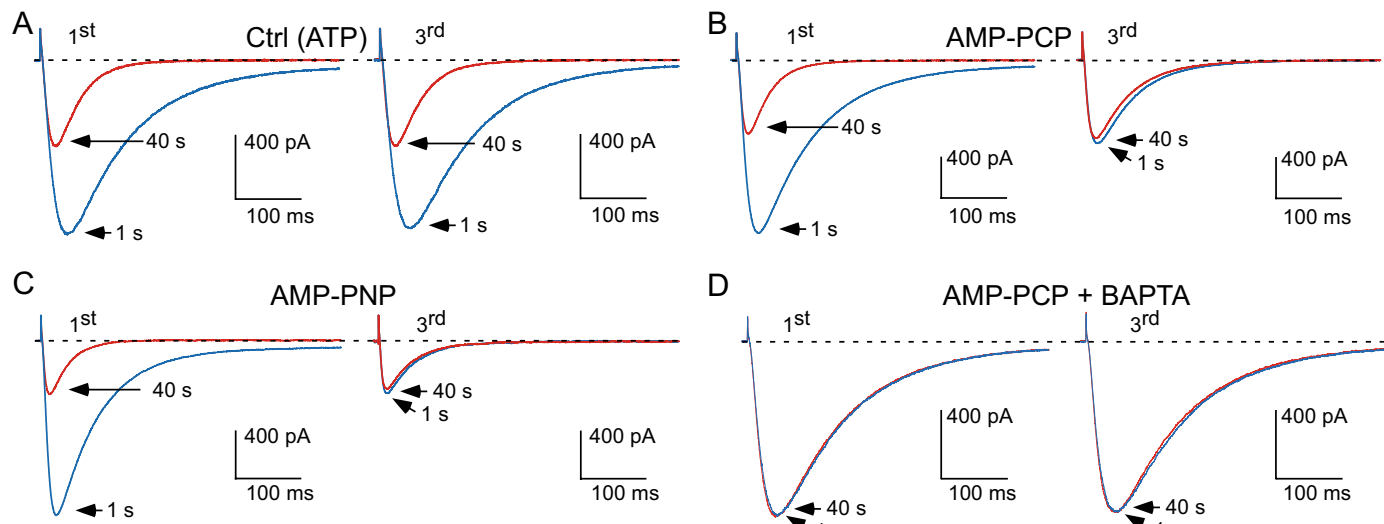

AMP-PNP

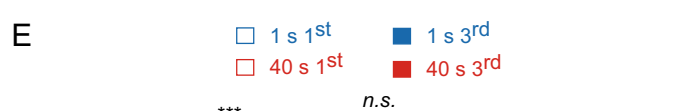

$\mathrm{D}$
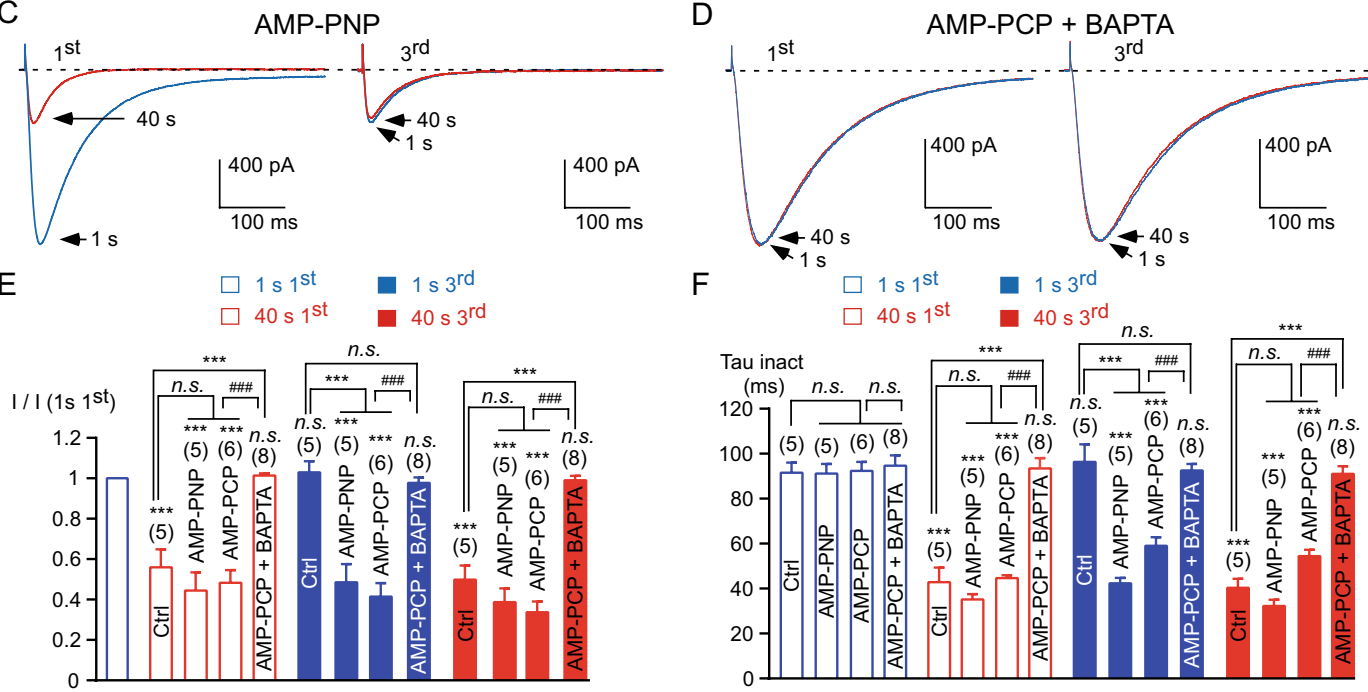

$\mathrm{F}$

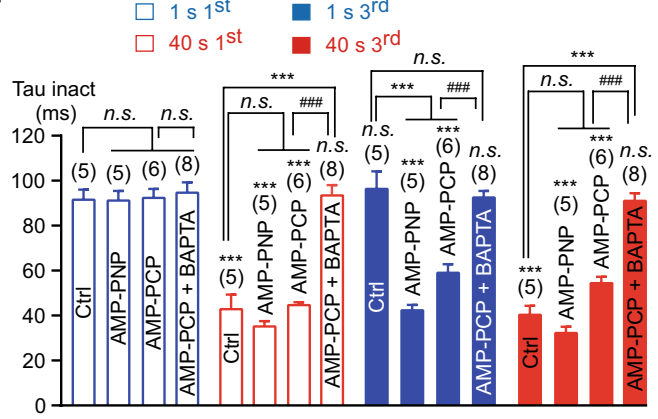

Figure 6. Intracellular ATP is required for the recovery of the $\mathrm{Ca}_{\mathrm{v}} 3.3$ current. (A-D) Examples of $\mathrm{Ca}_{\mathrm{v}} 3.3$ currents elicited by the $1 \mathrm{~Hz}$ stimulation protocol during $40 \mathrm{~s}$ for the $1^{\text {st }}$ and the $3^{\text {rd }}$ stimulation in cells dialyzed with $3 \mathrm{mM}$ ATP, Ctrl (A), in cells dialyzed with $3 \mathrm{mM}$ AMP-PCP (B), in cells dialyzed with $3 \mathrm{mM}$ AMP-PNP (C) and in cells dialyzed with $3 \mathrm{mM}$ AMP-PCP and $30 \mathrm{mM}$ BAPTA (D). (E) Amplitude of the $\mathrm{Ca}_{\mathrm{v}} 3.3$ current at the beginning $(1 \mathrm{~s})$ and after $40 \mathrm{~s}$ obtained at the $1^{\text {st }}$ and the $3^{\text {rd }}$ stimulation normalized to the initial current amplitude I $\left(1 \mathrm{~s}^{\text {st }}\right)$. (F) Inactivation kinetics of the $\mathrm{Ca}_{\mathrm{v}} 3.3$ current at the beginning of the stimulation ( $\left.1 \mathrm{~s}\right)$ and after $40 \mathrm{~s}$ stimulation obtained for the $1^{\text {st }}$ and the $3^{\text {rd }}$ stimulation. Asterisks indicate significant difference in the current amplitude (E) and inactivation kinetics (F), as compared to the initial current. In addition, variation in the current amplitude (E) and in inactivation kinetics $(\mathbf{F})$ as function of the treatment was statistically compared to the respective control condition, as indicated. The hash signs indicate statistical difference between AMPPCP and AMP-PCP + BAPTA. The number of cells tested is indicated into brackets. (n.s.: non-significant).

frequency of stimulation involves a yet undescribed transduction pathway. We next tested several other kinases that could possibly modulate $\mathrm{Ca}_{\mathrm{v}} 3.3$ current. We found that the presumed inhibition of PDK1 with OSU-03012, of AKT with AKT1/2 inhibitor, of PLK1/3 with GW843682X and BI 2536, of RSK with BI-D1870, of TAK1 with 5Z-oxozeanol, of MNK1 with CGP57380, of PYK2/FAK with PF-431396, of SGK with GSK 650394, of GSK3 with CT 99021, of SRC with SU6656, of eEF2 kinase with A484954 and of MLCK with ML7, was without significant effects on both inhibition and recovery of the $\mathrm{Ca}_{\mathrm{v}} 3.3$ current after the $1 \mathrm{~Hz}$ stimulation $(p>0.05$ as compared to the values obtained in the control condition, Supplementary Fig. 6A,B).

We also investigated the ATP-dependency of the recombinant $\mathrm{Ca}_{\mathrm{v}} 3.1$ current during fast stimulations (Fig. 7). In the presence of intracellular ATP, the $\mathrm{Ca}_{\mathrm{v}} 3.1$ current decreased $\sim 15 \%$ from its initial value during the $1 \mathrm{~Hz}$ frequency stimulation $(p<0.05$; Fig. 7A,C) with an acceleration of its inactivation kinetics $(p<0.05 ;$ Fig. 7A,D). Importantly, the $\mathrm{Ca}_{v} 3.1$ current recovery was almost total when the stimulation ceased for 3 minutes, as illustrated at the beginning of the $3^{\text {rd }}$ stimulation (Fig. 7A,C). In contrast, in AMP-PCP dialyzed cells, the $\mathrm{Ca}_{\mathrm{v}} 3.1$ current inhibition became irreversible ( $p<0.001$ as compared to the control condition, Fig. $7 \mathrm{~B}, \mathrm{C})$ and the remaining current displayed faster inactivation kinetics $(p<0.01$, Fig. $7 \mathrm{~B}, \mathrm{D})$. In addition, $\mathrm{Ca}_{\mathrm{v}} 3.1$ current inhibition in the presence of AMP-PCP $(\sim 35 \%$ inhibition, $p<0.001)$ was more potent than that observed in ATP dialyzed cells for the $1^{\text {st }}$ and the $3^{\text {rd }}$ stimulation $(p<0.05$, Fig. $7 \mathrm{~B}, \mathrm{C})$, indicating that current inhibition is a very dynamic process. Importantly, in cells dialyzed with AMP-PCP + BAPTA, the stimulation at $1 \mathrm{~Hz}$ did not produce current inhibition and the inactivation kinetics remained unchanged ( $p>0.05$, Fig. 7C,D).

We have previously demonstrated that current inhibition relies mainly on a hyperpolarizing shift in the steady-state inactivation of the $\mathrm{Ca}_{\mathrm{v}} 3.3$ current $^{15}$. Therefore, we have measured the steady-state inactivation of the $\mathrm{Ca}_{\mathrm{v}} 3.3$ current in the presence of non-hydrolysable ATP analogs. We found that, after the $3^{\text {rd }} 1 \mathrm{~Hz}$ stimulation in the presence of AMP-PCP, there was a strong hyperpolarizing shift $\sim 20 \mathrm{mV}$ in the steady-state inactivation of the $\mathrm{Ca}_{\mathrm{v}} 3.3$ current (Fig. $8 \mathrm{~A}, \mathrm{~B}$ ). In average, the $\mathrm{V}_{0.5}$ values of inactivation were $-69.2 \pm 0.6 \mathrm{mV}$ in the control condition and $-88.9 \pm 1.1 \mathrm{mV}$ in the presence of AMP-PCP $(p<0.001 ;$ Fig. $8 \mathrm{C})$. Similar findings were obtained for AMP-PNP dialyzed cells and for $\mathrm{NaN}_{3}$ treated cells (Fig. 8C) since the $\mathrm{V}_{0.5}$ values of the steady-state inactivation curves were $-88.7 \pm 2.2 \mathrm{mV}(p<0.001)$ and $-88.2 \pm 2.7 \mathrm{mV}(p<0.001)$, respectively. In contrast, we observed only a slight depolarizing shift in the presence of $\mathrm{Pi}\left(\mathrm{V}_{0.5}\right.$ was $-64.5 \pm 2.3 \mathrm{mV}$; Fig. $\left.8 \mathrm{C}\right)$, which was not 
A

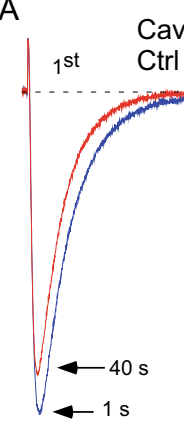

C

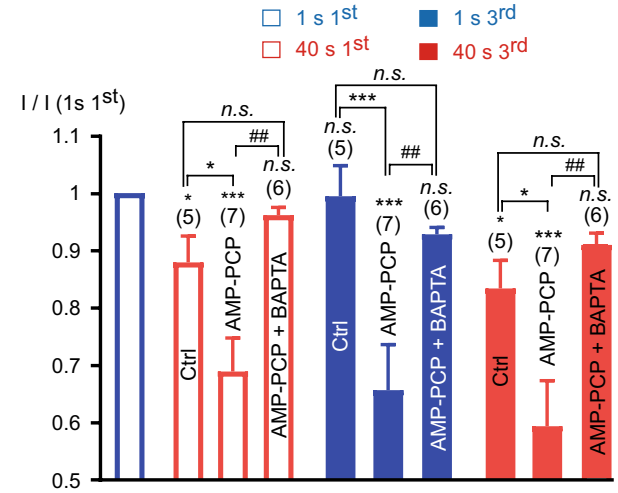

B

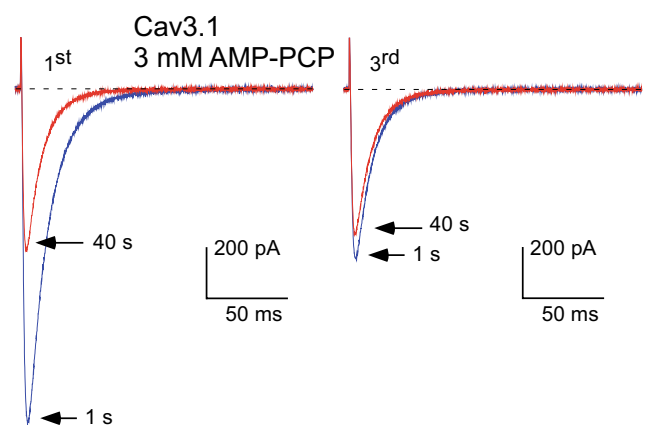

D

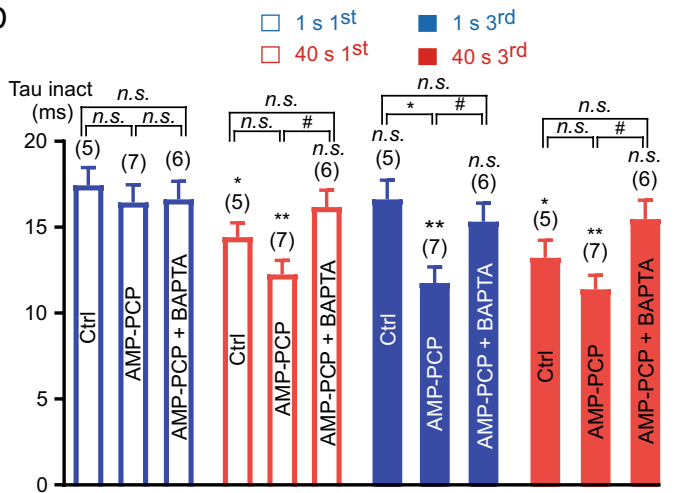

Figure 7. The recovery of the $\mathrm{Ca}_{\mathrm{v}} 3.1$ current after its inhibition by the $1 \mathrm{~Hz}$ stimulation required intracellular ATP. $(\mathbf{A}, \mathbf{B})$ Typical examples of $\mathrm{Ca}_{\mathrm{v}} 3.1$ currents elicited by the $1 \mathrm{~Hz}$ stimulation protocol during $40 \mathrm{~s}$ for the $1^{\text {st }}$ and the $3^{\text {rd }}$ stimulation in cells dialyzed with $3 \mathrm{mM}$ ATP, Ctrl (A) and in cells dialyzed with $3 \mathrm{mM}$ AMP-PCP (B). The $\mathrm{Ca}_{\mathrm{v}} 3.1$ currents were elicited using a $1 \mathrm{~Hz}$ test pulse stimulation at $-30 \mathrm{mV}$ (180 ms duration) from a $\mathrm{HP}$ of $-100 \mathrm{mV}$. (C) Amplitude of the $\mathrm{Ca}_{\mathrm{v}} 3.1$ current at the beginning ( $1 \mathrm{~s}$ ) and after $40 \mathrm{~s}$ obtained at the $1^{\text {st }}$ and the $3^{\text {rd }}$ stimulation normalized to the initial current amplitude I ( $\left.1 \mathrm{~s} 1^{\text {st }}\right)$. (D) Inactivation kinetics of the $\mathrm{Ca}_{\mathrm{v}} 3.1$ current at the beginning of the stimulation ( $\left.1 \mathrm{~s}\right)$ and after $40 \mathrm{~s}$ stimulation obtained for the $1^{\text {st }}$ and the $3^{\text {rd }}$ stimulation. Asterisks indicate significant difference in the current amplitude (C) and inactivation kinetics (D), as compared to the initial current. Variation in the current amplitude (C) and in inactivation kinetics (D) as function of the treatment was statistically compared to the respective control condition, as indicated. The hash signs indicate statistical difference between AMP-PCP and AMP-PCP + BAPTA. The number of cells tested is indicated into brackets. (n.s.: non-significant).

significant. Importantly, we found that in the presence of intracellular BAPTA, AMP-PCP produced no significant shift in the steady-state inactivation curve of the $\mathrm{Ca}_{\mathrm{v}} 3.3$ current $(p>0.05$, Fig. $8 \mathrm{C})$. Similar findings were obtained for the recombinant $\mathrm{Ca}_{\mathrm{v}} 3.1$ current since the steady-state inactivation was significantly shifted towards negative potentials by $\sim 8 \mathrm{mV}$ in the presence of AMP-PCP and this shift was abolished in the presence of BAPTA (Fig. 8D). In average we found that the $\mathrm{V}_{0.5}$ values of the steady-state inactivation curves for the $\mathrm{Ca}_{\mathrm{v}} 3.1$ current were $-80.6 \pm 1.3 \mathrm{mV}$ in the control condition, $-88.3 \pm 1.7 \mathrm{mV}$ for the AMP-PCP dialyzed cells $(p<0.01)$ and $-75.1 \pm 0.4 \mathrm{mV}$ for the cells dialyzed with AMP-PCP combined with BAPTA $(p<0.05$ as compared to the control condition, and $p<0.0001$ as compared to the AMP-PCP dialyzed cells).

We next explored whether a similar regulation of the native T-type current may occur in thalamic neurons. The effects of intracellular AMP-PCP and BAPTA were investigated in acute brain slices focusing on the T-type current expressed in the central medial nucleus (CeM) neurons of the thalamus, that are enriched in $\mathrm{Ca}_{\mathrm{v}} 3.1$ currents $^{27}$. In the presence of AMP-PCP, the T-type current amplitude in CeM neurons decreased during stimulation at the frequency of $1 \mathrm{~Hz}$ (Fig. 9A,B) and reached $\sim 15 \%$ inhibition after $40 \mathrm{~s}$ of stimulation $(p<0.01$, Fig. 9B,C). This decrease in the T-type current amplitude was prevented by the substitution of intracellular EGTA with BAPTA suggesting the role of local increase in intracellular $\mathrm{Ca}^{2+}$ concentration in current inhibition (Fig. 9B,C). As observed for recombinant T-type channels, steady-state inactivation of the T-type current in CeM neurons was shifted towards the negative potentials in the presence of AMP-PCP (Fig. 9D,E). This shift in the steady-state inactivation was similar to the one observed when ATP was omitted in the intracellular solution (Fig. 9E), suggesting that the ATP effect relies mainly on a putative phosphorylation mechanism. In average, the $\mathrm{V}_{0.5}$ values of the steady-state inactivation curves were $-75.4 \pm 1.6 \mathrm{mV}$ in the control condition with intracellular ATP, $-82.3 \pm 1.9 \mathrm{mV}$ for the cells dialyzed with an ATP-free solution $(p<0.05)$ and $-83.7 \pm 1.65 \mathrm{mV}$ for the cells dialyzed with AMP-PCP ( $p<0.01$, Fig. 9E). Importantly, the shift in the steady-state inactivation of the T-type current did not occur when the intracellular solution contained AMP-PCP in the presence of BAPTA $(p>0.05$ as compared to the control conditions, Fig. 9E). Overall, these data strongly suggest that the availability of both 
A

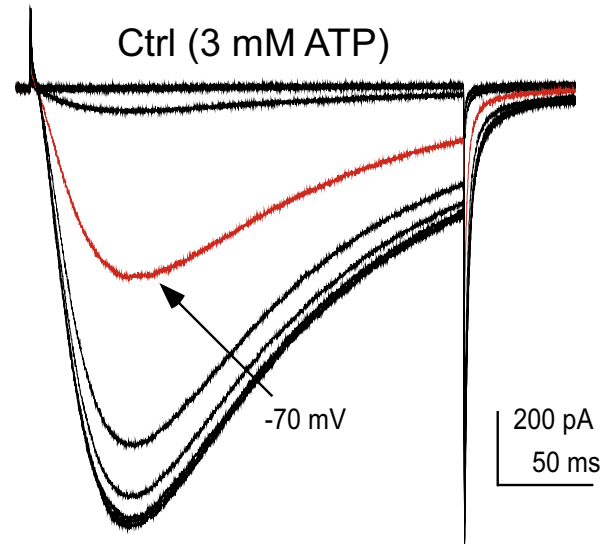

C

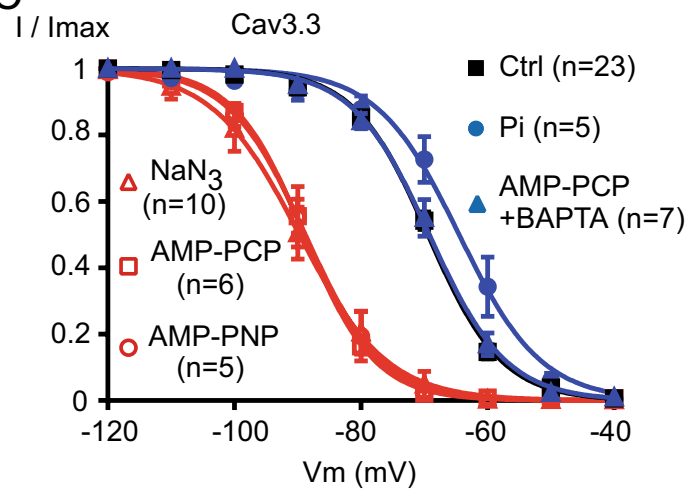

B

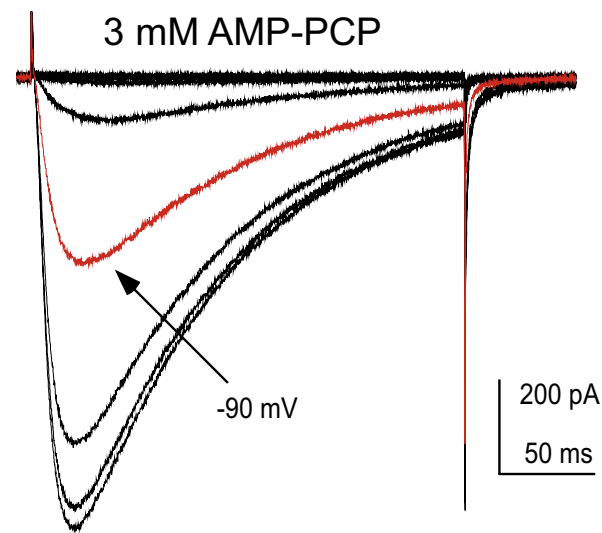

$\mathrm{D}$ I / Imax Cav3.1

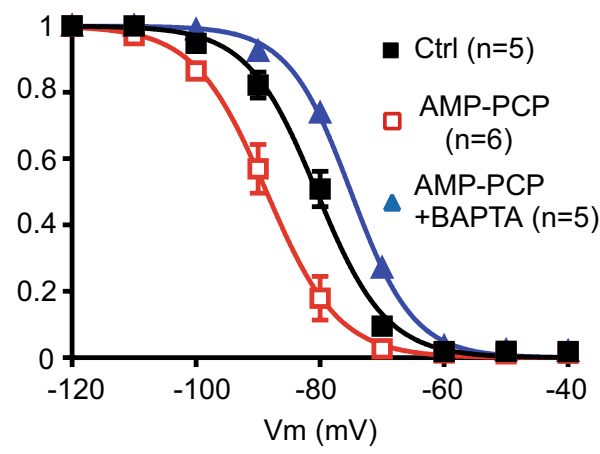

Figure 8. The steady-state inactivation of the $\mathrm{Ca}_{\mathrm{v}} 3$ current is dependent on intracellular ATP. (A,B) Typical $\mathrm{Ca}_{\mathrm{v}} 3.3$ currents recorded at $-30 \mathrm{mV}$ from holding potentials ranging from -120 to $-40 \mathrm{mV}(10 \mathrm{mV}$ increment, $5 \mathrm{~s}$ duration) obtained in the control condition (A, $3 \mathrm{mM} \mathrm{ATP})$ and in a cell dialyzed with $3 \mathrm{mM}$ AMP-PCP (B). The red trace indicates the half-inactivation potential. (C) Steady-state inactivation curves of the $\mathrm{Ca}_{\mathrm{v}} 3.3$ current obtained from experiments presented in $(\mathbf{A}, \mathbf{B})$. (D) Steady-state inactivation curves of the $\mathrm{Ca}_{\mathrm{v}} 3.1$ current from cells dialyzed with ATP (control condition), AMP-PCP and AMP-PCP combined with BAPTA.

recombinant and native T-type current depends on a phosphorylation process, which is regulated by the local concentration of intracellular calcium (see schematic representation in Supplementary Fig. 7).

\section{Discussion}

Recently, we demonstrated that the availability of the $\mathrm{Ca}_{\mathrm{v}} 3$ channels can be dynamically tuned by changes in the intracellular $\mathrm{Ca}^{2+}$ concentration at the vicinity of these channels ${ }^{15}$. Here we describe that this $\mathrm{Ca}^{2+}$-induced modulation of the $\mathrm{Ca}_{\mathrm{v}} 3$ current likely relies on a phosphorylation mechanism. This modulation occurs for both $\mathrm{Ca}_{\mathrm{v}} 3.3$ and $\mathrm{Ca}_{\mathrm{v}} 3.1$ recombinant channels, as well as for native neuronal T-type channels. Importantly, this modulation of T-type channels by intracellular $\mathrm{Ca}^{2+}$ is novel among the $\mathrm{Ca}^{2+}$ channel family as it involves a phosphorylation process not related to calcineurin, endocytosis and calmodulin-dependent pathways.

The regulation of the high-voltage-activated $\mathrm{Ca}_{\mathrm{v}} 1$ and $\mathrm{Ca}_{\mathrm{v}} 2 \mathrm{Ca}^{2+}$ channels by a rise in intracellular $\mathrm{Ca}^{2+}$ has been extensively studied and serves as a reference ${ }^{13,14,19-21,23-26}$. For the L-type / $\mathrm{Ca}_{\mathrm{v}} 1.2$ channel a rise in intracellular $\mathrm{Ca}^{2+}$ induces complex effects depending on the amount of the calcium ions. $\mathrm{Ca}^{2+}$ entry via L-type channels first induces a $\mathrm{Ca}^{2+}$-dependent inactivation (CDI) characterized by an acceleration of the inactivation kinetics of the L-type current that is followed, if the stimulation persists, by a decrease/rundown of the current. It was established that both $\mathrm{CDI}^{14,19-21,24}$ and rundown ${ }^{23,24}$ of the L-type current are dependent on calmodulin activity. Clearly, the modulation of the $\mathrm{Ca}_{\mathrm{v}} 3.3$ current described here is independent of the calmodulin-dependent pathway, contrasting with the well-established $\mathrm{Ca}^{2+}$-dependent mechanisms regulating the L-type channels.

Importantly recent studies have revealed that calmodulin interacts with $\mathrm{Ca}_{\mathrm{v}} 3$ channels ${ }^{16-18}$. We have previously reported that the steady-state inactivation of the $\mathrm{Ca}_{\mathrm{v}} 3.2$ current was negatively shifted $\sim 5 \mathrm{mV}$ towards negative potentials in the presence of the $\mathrm{CaM}_{1234}$ mutant that does not bind $\mathrm{Ca}^{2+17}$, and we find here that this is also the case with the $\mathrm{Ca}_{\mathrm{v}} 3.3$ current. However, in the presence of this mutant, the inhibition of $\mathrm{Ca}_{\mathrm{v}} 3.3$ current at a high frequency of stimulation is preserved as well as the current recovery after the stopping of the stimulation. Similar findings were obtained using a CaMKII peptide that binds CaM and inhibits its function. In contrast with our results, another study found that in the presence of $1 \mu \mathrm{M}$ intracellular $\mathrm{Ca}^{2+}$, the steady-state inactivation of 
A

$$
-90 \mathrm{mV} \backsim \underset{\text { AMP-PCP }}{\mathrm{x} 40} @ 1 \mathrm{~Hz} \quad \text { native T-type (CeM) }
$$

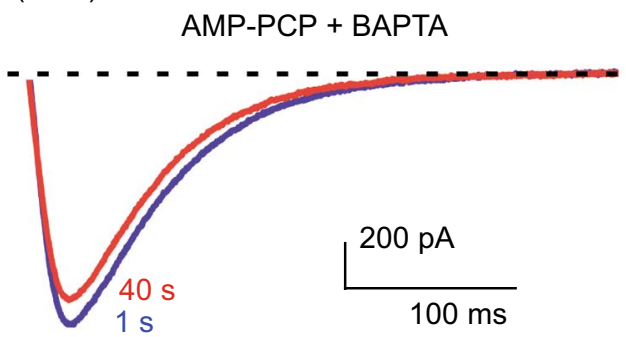

B Normalized
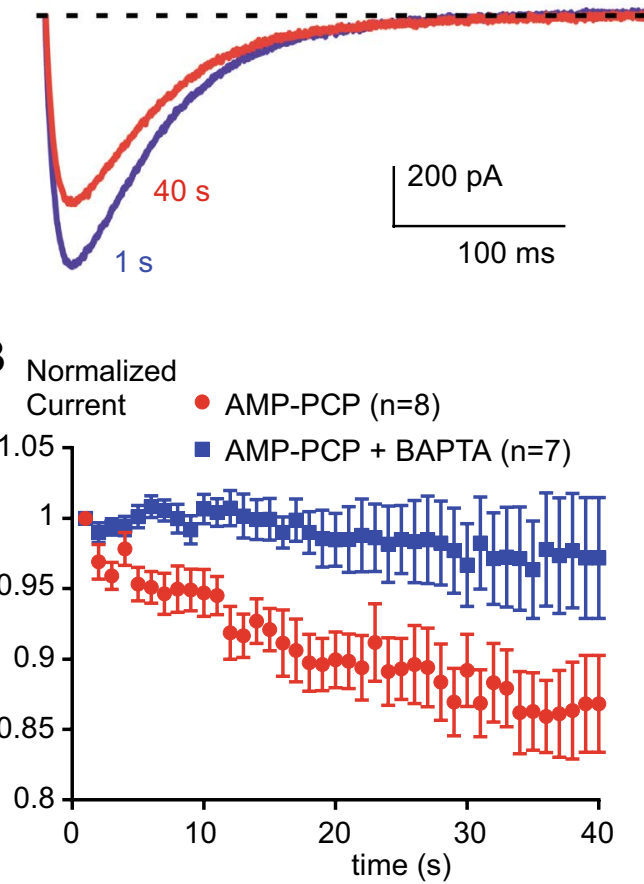

C

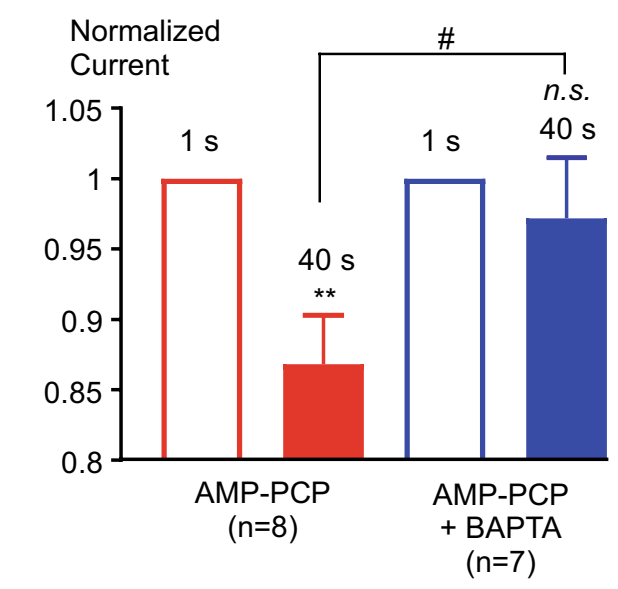

D

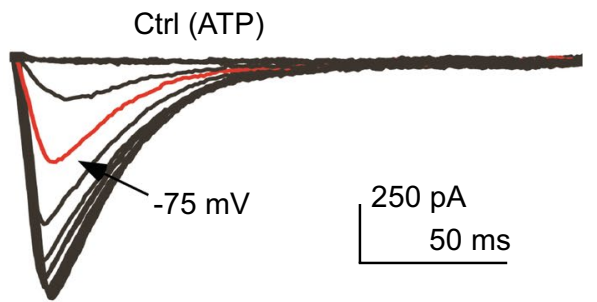

$\mathrm{E}$
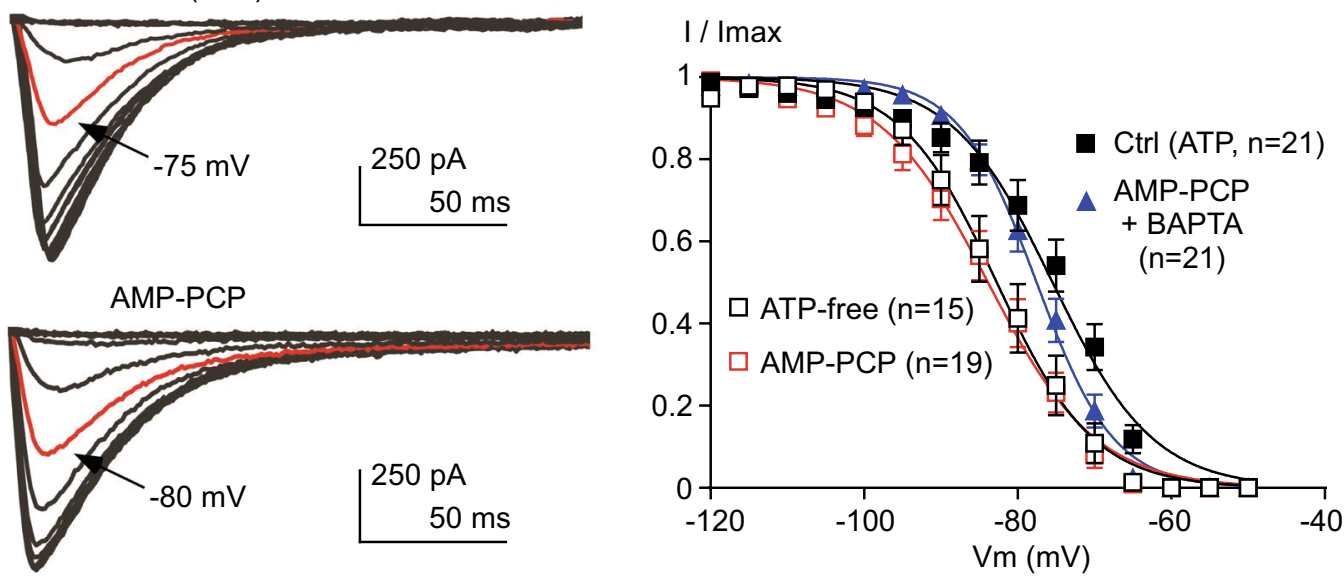

Figure 9. The native T-type current from neurons of rat central medial (CeM) nucleus is regulated by an interplay between a rise in intracellular calcium and a phosphorylation mechanism. (A) Typical T-type current elicited by stimulation at $-30 \mathrm{mV}$ applied at a frequency of $1 \mathrm{~Hz}$ from a holding potential of $-90 \mathrm{mV}$ obtained from CeM neurons dialyzed with either AMP-PCP or AMP-PCP combined with BAPTA. (B) Normalized current amplitude from 1 to $40 \mathrm{~s}$. (C) Average normalized current amplitude recorded at $1 \mathrm{~s}$ and at $40 \mathrm{~s}$. Asterisks indicate significant difference in the current amplitude at $40 \mathrm{~s}$ as compared to the current amplitude at $1 \mathrm{~s}$. The hash signs indicate statistical difference between AMP-PCP and AMP-PCP + BAPTA. (D) Representative T-type current recorded at $-50 \mathrm{mV}$ from holding potentials ranging from -120 to $-50 \mathrm{mV}$ ( $5 \mathrm{mV}$ increment, $3.6 \mathrm{~s}$ duration). CeM neurons were dialyzed with either ATP (control condition) or AMP-PCP. The red trace indicates the half-inactivation potential. (E) Average steady-state inactivation curves obtained from experiments presented in (D) for neurons dialyzed with ATP (control), AMP-PCP, AMP-PCP combined with BAPTA, and in absence of ATP (ATP-free).

the $\mathrm{Ca}_{\mathrm{v}} 3.3$ current is shifted $\sim 6 \mathrm{mV}$ towards negative potentials and this effect is occluded by the over-expression of the $\mathrm{CaM}_{1234}$ mutant ${ }^{18}$. This suggest that a prolonged and global increase in intracellular $\mathrm{Ca}^{2+18}$ may lead to the activation of distinct intracellular pathways, as compared to a transient and local increase in intracellular $\mathrm{Ca}^{2+}$, which occurs here during the fast stimulation of the $\mathrm{Ca}_{v} 3.3$ current. The $\mathrm{Ca}^{2+} / \mathrm{CaM}$-activated phosphatase 
calcineurin was also shown to interact with $\mathrm{Ca}_{\mathrm{v}} 3.2$ channels and $\mathrm{Ca}^{2+}$ entry via these channels induces the calcineurin-dependent activation of the transcription factor NFAT ${ }^{43-45}$. In addition, both L-type current decrease during fast stimulation and CDI were prevented after calcineurin inhibition ${ }^{23,24}$, suggesting that calcineurin may mediate inhibition of the $\mathrm{Ca}_{\mathrm{v}} 3.3$ current. However, prolonged treatment with several calcineurin inhibitors was without effect on $\mathrm{Ca}_{\mathrm{v}} 3.3$ current modulation, confirming a study on T-type currents in sensory neurons ${ }^{46}$. It was also demonstrated that $\mathrm{Ca}^{2+}$ entry via $\mathrm{Ca}_{\mathrm{v}} 3$ channels can promote a $\mathrm{Ca}^{2+}$-dependent $\mathrm{CaM}$ dissociation from the channels leading to CaMKII activation, which is blocked using the CaMKII inhibitory peptide $\mathrm{AIP}^{16}$. In addition, in the presence of micromolar concentrations of intracellular $\mathrm{Ca}^{2+}$, CaMKII can regulate $\mathrm{Ca}_{\mathrm{v}} 3.2$ current by phosphorylation of serine residues 1198 and 1153 in the channel's $2-3$ intracellular loop ${ }^{47-49}$. This regulation is abolished in the presence of the AIP peptide or by substitution of intracellular ATP by AMP-PNP ${ }^{47}$. However, this latter regulation of the $\mathrm{Ca}_{v} 3.2$ current is clearly different from the one described here for the $\mathrm{Ca}_{v} 3.3$ current, since $\mathrm{Ca}^{2+} / \mathrm{CaMKII}$ activation promotes an increase (but not inhibition) of the $\mathrm{Ca}_{\mathrm{v}} 3.2$ current by promoting a negative shift in the activation curve without any effect on the steady-state inactivation. In addition, this $\mathrm{Ca}_{\mathrm{v}} 3.2$ regulation involves CaMKII $\gamma$ c, which is not expressed in HEK-293 cells ${ }^{47}$. Accordingly, we found that the dialysis of the AIP peptide had no effect on both inhibition and recovery of the $\mathrm{Ca}_{\mathrm{v}} 3.3$ current. Therefore, although CaM/ Calcineurin/CaMKII pathways interact with $\mathrm{Ca}_{\mathrm{v}} 3$ channels, our data strongly support the idea that the modulation of the $\mathrm{Ca}_{v} 3.3$ current at a high frequency of stimulation requires additional $\mathrm{Ca}^{2+}$-dependent mechanisms.

Endocytosis could be another mechanism leading to the decrease of the $\mathrm{Ca}_{v} 3.3$ current. Indeed, for the L-type channels, a prolonged current stimulation or activation of the ionotropic NMDA receptors induces the internalization of the channels and potentially their degradation in lysosomes or their recycling to the plasma membrane depending of the amount and the duration of the $\mathrm{Ca}^{2+}$ entry ${ }^{21,25,26}$. These studies have highlighted the crucial role of dynamin 1, a GTPase required for the formation of endocytic vesicles from the plasma membrane ${ }^{28}$, in the early steps of this process ${ }^{21,25,26}$. In the presence of a dominant negative mutant of dynamin 1 (Dyn $1 \mathrm{~K} 44 \mathrm{~A}$ ), which abolishes the endocytosis of the L-type channel ${ }^{25}$, the inhibition of the $\mathrm{Ca}_{\mathrm{v}} 3.3$ current during $1 \mathrm{~Hz}$ stimulation is not affected as well as its recovery when the stimulation ceases. In addition, a role of lysosomal degradation is unlikely since $\mathrm{Ca}_{\mathrm{v}} 3.3$ current inhibition and its recovery are preserved after treatment of the cells with bafilomycin, which prevents degradation of the L-type channel ${ }^{26}$. Therefore, although the regulation by intracellular $\mathrm{Ca}^{2+}$ of L- and T-type channels share similar features, the mechanism underlying the $\mathrm{Ca}^{2+}$ dependent inhibition of T-type channels during fast stimulation is clearly different from the one described for L-type channels.

We found that the $\mathrm{Ca}_{\mathrm{v}} 3.3$ current modulation observed at a high frequency of stimulation likely relies on a phosphorylation mechanism (see schematic representation in Supplementary Fig. 7). Accordingly, the inhibition of the $\mathrm{Ca}_{\mathrm{v}} 3.3$ current during fast stimulation is decreased in a presence of intracellular Pi, which is a competitive inhibitor of phosphatase activities ${ }^{30,31}$. Conversely, sodium azide, a pharmacological agent that promotes the depletion of intracellular ATP by the inhibition of cytochrome oxidase ${ }^{33}$, the final enzyme in the mitochondrial electron transport chain, abolishes the recovery of the $\mathrm{Ca}_{v} 3.3$ current after its inhibition induced by the fast stimulation. Therefore, we hypothesized that ATP is necessary in the recovery process. We used non-hydrolysable ATP analogs, AMP-PNP and AMP-PCP, which are competitive inhibitors of reactions requiring hydrolysable $\mathrm{ATP}^{50}$. The substitution of intracellular ATP with AMP-PNP or AMP-PCP, abolishes the recovery of the Ca 3.3 current, indicating the crucial role of a phosphorylation-dependent mechanism in the $\mathrm{Ca}^{2+}$-induced inhibition of the $\mathrm{Ca}_{\mathrm{v}} 3.3$ current. This depression of recovery in AMP-PCP dialyzed cells might be a consequence of a rundown of the $\mathrm{Ca}_{\mathrm{v}} 3.3$ current during the experiment leading to an apparent inhibition of recovery after fast stimulation. However, we found a similar rundown of the $\mathrm{Ca}_{\mathrm{v}} 3.3$ current when stimulated at a low frequency in ATP and in AMP-PCP dialyzed cells, indicating that the effect of AMP-PCP depends on the previous inhibition of the $\mathrm{Ca}_{\mathrm{v}} 3.3$ current by a fast stimulation. Accordingly, in the presence of intracellular BAPTA, which prevents a local submembrane rise in $\mathrm{Ca}^{2+51-53}$, AMP-PCP did not produce current inhibition indicating that the effect of non-hydrolysable ATP analogs relies on a $\mathrm{Ca}^{2+}$-dependent mechanism.

We used different pharmacological antagonists to examine the potential involvement of various intracellular pathways underlying the $\mathrm{Ca}_{\mathrm{v}} 3.3$ current modulation. Interestingly, the recovery of the $\mathrm{Ca}_{\mathrm{v}} 3.3$ current after fast stimulation does not depend of the previously identified kinases that modulated the $\mathrm{Ca}_{\mathrm{v}} 3$ current, including PKA, PKC and Rho-associated kinase ${ }^{34-37,39}$. The recovery of the $\mathrm{Ca}_{\mathrm{v}} 3.3$ current is also resistant to the inhibition of PI3K / PI4K, PDK1, AKT, PLK1/3, RSK, TAK1, PYK2/FAK, SGK, GSK3, SRC, eEF2 or MLCK. Therefore, further extensive biochemical and electrophysiological studies are needed to identify the precise signaling pathways that modulate the $\mathrm{Ca}_{\mathrm{v}} 3.3$ current.

We have previously demonstrated that a rise in submembrane $\mathrm{Ca}^{2+}$ ions induces a hyperpolarizing shift in the steady-state inactivation of the $\mathrm{Ca}_{\mathrm{v}} 3.3$ current, a regulation that is also found for the $\mathrm{Ca}_{\mathrm{v}} 3.1$ current $^{15}$. Here we show that sodium azide, AMP-PNP and AMP-PCP treatment, induced a large $\sim 20 \mathrm{mV}$ hyperpolarizing shift in the steady-state inactivation of the $\mathrm{Ca}_{\mathrm{v}} 3.3$ current, confirming a common mechanism. Accordingly, AMP-PCP has no effect on the steady-state inactivation of the $\mathrm{Ca}_{v} 3.3$ current in cells dialyzed with BAPTA. Regarding the $\mathrm{Ca}_{\mathrm{v}} 3.1$ current, its inhibition during stimulation at a high frequency in the presence of intracellular ATP is modest $(\sim 15 \%)$ compared to $\mathrm{Ca}_{\mathrm{v}} 3.3$, most likely due to its rapid inactivation kinetics leading to a moderate increase in intracellular $\mathrm{Ca}^{2+54-56}$. As observed for the $\mathrm{Ca}_{\mathrm{v}} 3.3$ current, the inhibition of the $\mathrm{Ca}_{\mathrm{v}} 3.1$ current is irreversible in the presence of intracellular AMP-PCP whereas the inhibition is prevented in the presence of BAPTA. In addition, the steady-state inactivation curve of the $\mathrm{Ca}_{v} 3.1$ current is shifted by $\sim 8 \mathrm{mV}$ towards negative potentials in the presence of AMP-PCP. Therefore, our data reveal that the T-type channel modulation by intracellular $\mathrm{Ca}^{2+}$ has unusual features among the $\mathrm{Ca}^{2+}$ channel family both in its transduction and its underlying biophysical mechanisms.

Importantly, we found that the native $\mathrm{Ca}_{\mathrm{v}} 3.1 \mathrm{~T}$-type current recorded in neurons of the central medial nucleus $(\mathrm{CeM})$ of the thalamus ${ }^{27}$, is subject to a similar $\mathrm{Ca}^{2+}$-dependent regulation. When stimulated at a frequency of $1 \mathrm{~Hz}$, the T-type current in CeM neurons decreases $~ 15 \%$ in the presence of AMP-PCP and this effect is abolished in 
the presence of intracellular BAPTA. As observed for recombinant channels, this inhibition relies on a shift of the steady-state inactivation since the native T-type current displays a $\sim 8 \mathrm{mV}$ negative shift in the steady-state inactivation curve in the presence of AMP-PCP, which is abolished in the presence of BAPTA. This shift is similar to the one observed in cells dialyzed with an ATP-free solution, indicating that ATP effect relies on a phosphorylation mechanism. Interestingly, it was previously reported in thalamocortical neurons of the ventrobasal nucleus that the steady-state inactivation of the T-type current progressively shifts towards negative potentials during the dialysis of an ATP-free solution, indicating that the ATP-dependency of the T-type channel availability is not restricted to CeM neurons $s^{57}$. Overall, our study demonstrates that the availability of both recombinant and native T-type channels depends on a phosphorylation process regulated by the local intracellular $\mathrm{Ca}^{2+}$ concentration (Supplementary Fig. 7). This $\mathrm{Ca}^{2+}$-dependent inhibition of T-type channel would provide an important feedback mechanism during sustained neuronal activities to limit intracellular $\mathrm{Ca}^{2+}$ overload. It should be noted however that although our study highlights the role of a putative phosphorylation mechanism, whether the $\mathrm{Ca}_{v} 3$ channel is directly phosphorylated or modulated via an intermediate protein remains an open question. Future molecular and biochemical studies will be necessary to clarify this important aspect and identify the key residues implicated in the $\mathrm{Ca}_{\mathrm{v}} 3$ current regulation.

By demonstrating that the availability of the T-type channels critically depends on an interplay between $\mathrm{Ca}^{2+}$ entry and the cellular phosphorylation status, we document a novel and important mechanism that tightly and dynamically controls T-type channel activity. Considering that T-type channels are widely expressed in the central nervous system where they contribute to the rebound burst firing activities ${ }^{6,7}$, and that an alteration in their activity is implicated in several neuronal disorders, including epilepsy, schizophrenia, autism, chronic pain and cerebellar ataxia ${ }^{2,8,10-12}$, this phosphorylation-dependent $\mathrm{Ca}^{2+}$-sensitive mechanism might be crucial to accurately balance the electrical and $\mathrm{Ca}^{2+}$ signaling of T-type channels both in their normal physiological responses and in disease states involving these channels.

\section{Methods}

Cell culture, transfection and electrophysiological recordings in tsA-201 cells. Cell culture and transfection of tsA-201 cells were performed as described previously ${ }^{15}$. Briefly, transfections were performed using jet-PEI (Ozyme, France) with a DNA mix (1.5 $\mu$ g total) containing $0.5 \%$ of a GFP encoding plasmid and 99.5\% of the pcDNA3.1 plasmid constructs that code for the human $\mathrm{Ca}_{\mathrm{v}} 3.1$ (isoform $\mathrm{Ca}_{\mathrm{v}} 3.1 \mathrm{a}$, Genbank accession number AF126966.1 $1^{58}$ ) and human $\mathrm{Ca}_{\mathrm{v}} 3.3$ (isoform LT9, Genbank accession number AF393329.1 ${ }^{59}$ ) channels. In some experiments, $1.5 \mu \mathrm{g}$ of the plasmids that code for Dynamin 1, Dynamin $1 \mathrm{~K} 44 \mathrm{~A}, \mathrm{AP}-2, \mathrm{CaM}_{1234}$ or $\beta \mathrm{ARK}-\mathrm{Ct}$ was added to the DNA mix. Two days after transfection, tsA-201 cells were dissociated with Versene (Invitrogen, Fisher Scientific, France) and plated at low density for electrophysiological recordings, as described previously ${ }^{15}$. Macroscopic currents were recorded at room temperature using an internal solution containing (in mM): $140 \mathrm{CsCl}$, 10 EGTA, 10 HEPES, $3 \mathrm{Mg}$-ATP, $0.6 \mathrm{GTPNa}$, and $3 \mathrm{CaCl}_{2}$ (pH adjusted to 7.25 with $\mathrm{KOH}, \sim 315 \mathrm{mOsm}, \sim 100 \mathrm{nM}$ free $\mathrm{Ca}^{2+}$ using the MaxChelator software, http://maxchelator.stanford.edu/) and an extracellular solution containing (in mM): $135 \mathrm{NaCl}, 20 \mathrm{TEACl}, 2 \mathrm{CaCl}_{2}, 1 \mathrm{MgCl}_{2}$, and $10 \mathrm{HEPES}$ (pH adjusted to 7.25 with $\mathrm{KOH}, \sim 330 \mathrm{mOsm}$ ).

In vitro brain slice preparation from juvenile rats. Experimental procedures with animals were performed as described previously ${ }^{27}$ according to the protocol \#B-111616 (02) 1E approved by the Animal Care and Use Committee at the University of Colorado Anschutz Medical Campus. Treatments of rats adhered to guidelines set forth in the NIH Guide for the Care and Use of Laboratory Animals. All efforts were made to minimize animal suffering and to use only the number of animals necessary to produce reliable scientific data. Experiments were performed on male and female Sprague-Dawley rats (P23-P26) obtained from Envigo (Indianapolis, IN, USA). Brain slice preparation was obtained as described previously ${ }^{27}$. Brain slices were immediately incubated for $30 \mathrm{~min}$ in the following solution (in $\mathrm{mM}$ ): $124 \mathrm{NaCl}, 10$ D-glucose, $26 \mathrm{NaHCO}_{3}, 1.25 \mathrm{NaH}_{2} \mathrm{PO}_{4}, 4 \mathrm{KCl}, 2 \mathrm{CaCl}_{2}$, $2 \mathrm{MgCl}_{2}$ at $37^{\circ} \mathrm{C}$ before use in electrophysiology experiments, which were done at room temperature. During incubation, slices were constantly perfused with a gas mixture of $95 \mathrm{vol} \% \mathrm{O}_{2}$ and $5 \mathrm{vol} \% \mathrm{CO}_{2}$.

Electrophysiological recordings in CeM neurons. Whole-cell recordings were performed in CeM neurons, as described previously ${ }^{27}$. The external solution contained (in mM): $125 \mathrm{NaCl}, 25 \mathrm{D}$-glucose, $25 \mathrm{NaHCO}_{3}, 1.25$ $\mathrm{NaH}_{2} \mathrm{PO}_{4}, 2.5 \mathrm{KCl}, 1 \mathrm{MgCl}_{2}, 2 \mathrm{CaCl}_{2}$. The voltage-dependent sodium current blocker tetrodotoxin (TTX; $\left.1 \mu \mathrm{M}\right)$ was added to the extracellular medium. The internal solution for voltage-clamp experiments with Cesium (Cs) containing ATP solution consisted of the following (in mM): 110 Cs-methane sulfonate, 14 phosphocreatine, 10 HEPES, 9 EGTA, $5 \mathrm{Mg}$-ATP, and 0.3 Tris-GTP, pH adjusted to 7.15 to 7.20 with $\mathrm{CsOH}$ ( $300 \mathrm{mOsm})$. The ATP-free internal consisted of the following (in mM): 110 Cs methane sulfonate, 10 HEPES, 9 EGTA. The AMP-PCP based internals had $3 \mathrm{mM}$ AMP-PCP instead of Mg-ATP. AMP-PCP solution with BAPTA had $30 \mathrm{mM}$ BAPTA as an alternative to EGTA.

Data analysis. Current traces were analyzed using pCLAMP9 (Molecular Devices) and GraphPad Prism (GraphPad) softwares. Steady-state inactivation curves were fitted using the Boltzmann equation where I/I $\max =1 /\left(1+\exp \left(\left(\mathrm{Vm}-\mathrm{V}_{0.5}\right) /\right.\right.$ slope factor $\left.)\right)$. Results are presented as the mean $\pm \mathrm{SEM}$, and $\mathrm{n}$ is the number of cells. Statistical analysis were performed with two-way ANOVA combined with a Tukey post-test for multiple comparisons, excepted in Fig. 1, for which a one-way ANOVA combined with a Tukey post-test for multiple comparisons was used $(* p<0.05, * * p<0.01, * * * p<0.001)$.

Chemical reagents. The CaMKII 290-309 peptide, the autocamtide-2-related inhibitory peptide (AIP) and the calcineurin inhibitory peptide (CIP) were obtained from Enzo life science (France). STO-609, BIM IX, BI 2536, BI-D1870, SU6656 and A484954 were obtained from Cayman Chemical (Interchim Inc., France). OSU03012, AKT1/2 I, GW843682X, 5Z-oxozeaenol, CGP 57380, PF-431396, GSK 650394, CT 99021 and ML-7 were purchased from Tocris (R\&D Systems Europe, France). All others compounds were obtained from Sigma (France). The control experiments were performed using the corresponding solvent. 
Received: 4 February 2019; Accepted: 13 October 2019;

Published online: 30 October 2019

\section{References}

1. Zamponi, G. W., Striessnig, J., Koschak, A. \& Dolphin, A. C. The Physiology, Pathology, and Pharmacology of Voltage-Gated Calcium Channels and Their Future Therapeutic Potential. Pharmacol Rev 67, 821-870, https://doi.org/10.1124/pr.114.009654 (2015).

2. Zamponi, G. W. Targeting voltage-gated calcium channels in neurological and psychiatric diseases. Nat Rev Drug Discov 15, 19-34, https://doi.org/10.1038/nrd.2015.5 (2016).

3. Eckert, R. \& Chad, J. E. Inactivation of Ca channels. Prog Biophys Mol Biol 44, 215-267 (1984).

4. Ben-Johny, M. \& Yue, D. T. Calmodulin regulation (calmodulation) of voltage-gated calcium channels. J Gen Physiol 143, 679-692, https://doi.org/10.1085/jgp.201311153 (2014).

5. Ertel, E. A. et al. Nomenclature of voltage-gated calcium channels. Neuron 25, 533-535 (2000).

6. Huguenard, J. R. Low-threshold calcium currents in central nervous system neurons. Annu Rev Physiol 58, 329-348, https://doi. org/10.1146/annurev.ph.58.030196.001553 (1996).

7. Perez-Reyes, E. Molecular physiology of low-voltage-activated t-type calcium channels. Physiol Rev 83, 117-161, https://doi. org/10.1152/physrev.00018.2002 (2003).

8. Beenhakker, M. P. \& Huguenard, J. R. Neurons that fire together also conspire together: is normal sleep circuitry hijacked to generate epilepsy? Neuron 62, 612-632, https://doi.org/10.1016/j.neuron.2009.05.015 (2009).

9. Crunelli, V., David, F., Leresche, N. \& Lambert, R. C. Role for T-type $\mathrm{Ca}^{2+}$ channels in sleep waves. Pflugers Arch 466, 735-745, https://doi.org/10.1007/s00424-014-1477-3 (2014).

10. Todorovic, S. M. \& Jevtovic-Todorovic, V. T-type voltage-gated calcium channels as targets for the development of novel pain therapies. Br J Pharmacol 163, 484-495, https://doi.org/10.1111/j.1476-5381.2011.01256.x (2011).

11. Andrade, A. et al. A rare schizophrenia risk variant of CACNA1I disrupts CaV3.3 channel activity. Sci Rep 6, 34233, https://doi. org/10.1038/srep34233 (2016).

12. Chemin, J. et al. De novo mutation screening in childhood-onset cerebellar atrophy identifies gain-of-function mutations in the CACNA1G calcium channel gene. Brain 141, 1998-2013, https://doi.org/10.1093/brain/awy145 (2018).

13. Liang, H. et al. Unified mechanisms of $\mathrm{Ca}^{2+}$ regulation across the $\mathrm{Ca}^{2+}$ channel family. Neuron 39, 951-960 (2003).

14. Dick, I. E. et al. A modular switch for spatial $\mathrm{Ca}^{2+}$ selectivity in the calmodulin regulation of CaV channels. Nature 451, 830-834, https://doi.org/10.1038/nature06529 (2008).

15. Cazade, M., Bidaud, I., Lory, P. \& Chemin, J. Activity-dependent regulation of T-type calcium channels by submembrane calcium ions. Elife 6, https://doi.org/10.7554/eLife.22331 (2017).

16. Asmara, H. et al. A T-type channel-calmodulin complex triggers alphaCaMKII activation. Mol Brain 10, 37, https://doi.org/10.1186/ s13041-017-0317-8 (2017).

17. Chemin, J. et al. Calmodulin regulates Cav3 T-type channels at their gating brake. J Biol Chem, https://doi.org/10.1074/jbc. M117.807925 (2017).

18. Lee, N. et al. $\mathrm{Ca}^{2+}$ Regulation of Cav3.3 T-type $\mathrm{Ca}^{2+}$ Channel Is Mediated by Calmodulin. Mol Pharmacol 92, 347-357, https://doi. org/10.1124/mol.117.108530 (2017).

19. Peterson, B. Z., DeMaria, C. D., Adelman, J. P. \& Yue, D. T. Calmodulin is the $\mathrm{Ca}^{2+}$ sensor for Ca ${ }^{2+}$-dependent inactivation of L-type calcium channels. Neuron 22, 549-558 (1999).

20. Zuhlke, R. D., Pitt, G. S., Deisseroth, K., Tsien, R. W. \& Reuter, H. Calmodulin supports both inactivation and facilitation of L-type calcium channels. Nature 399, 159-162, https://doi.org/10.1038/20200 (1999).

21. Hall, D. D. et al. Competition between alpha-actinin and $\mathrm{Ca}(2)(+)$-calmodulin controls surface retention of the $\mathrm{L}-$ type $\mathrm{Ca}(2)(+)$ channel Ca(V)1.2. Neuron 78, 483-497, https://doi.org/10.1016/j.neuron.2013.02.032 (2013).

22. Ben-Johny, M. et al. Conservation of $\mathrm{Ca}^{2+} /$ calmodulin regulation across $\mathrm{Na}$ and $\mathrm{Ca}^{2+}$ channels. Cell 157, 1657-1670, https://doi. org/10.1016/j.cell.2014.04.035 (2014).

23. Oliveria, S. F., Dell'Acqua, M. L. \& Sather, W. A. AKAP79/150 anchoring of calcineurin controls neuronal L-type Ca ${ }^{2+}$ channel activity and nuclear signaling. Neuron 55, 261-275, https://doi.org/10.1016/j.neuron.2007.06.032 (2007).

24. Oliveria, S. F., Dittmer, P. J., Youn, D. H., Dell'Acqua, M. L. \& Sather, W. A. Localized calcineurin confers Ca ${ }^{2+}$-dependent inactivation on neuronal L-type $\mathrm{Ca}^{2+}$ channels. J Neurosci 32, 15328-15337, https://doi.org/10.1523/JNEUROSCI.2302-12.2012 (2012).

25. Green, E. M., Barrett, C. F., Bultynck, G., Shamah, S. M. \& Dolmetsch, R. E. The tumor suppressor eIF3e mediates calcium-dependent internalization of the L-type calcium channel CaV1.2. Neuron 55, 615-632, https://doi.org/10.1016/j.neuron.2007.07.024 (2007).

26. Tsuruta, F., Green, E. M., Rousset, M. \& Dolmetsch, R. E. PIKfyve regulates CaV1.2 degradation and prevents excitotoxic cell death. J Cell Biol 187, 279-294, https://doi.org/10.1083/jcb.200903028 (2009).

27. Stamenic, T. T. \& Todorovic, S. M. Cytosolic ATP Relieves Voltage-Dependent Inactivation of T-Type Calcium Channels and Facilitates Excitability of Neurons in the Rat Central Medial Thalamus. eNeuro 5, https://doi.org/10.1523/ENEURO.0016-18.2018 (2018).

28. Praefcke, G. J. \& McMahon, H. T. The dynamin superfamily: universal membrane tubulation and fission molecules? Nat Rev Mol Cell Biol 5, 133-147, https://doi.org/10.1038/nrm1313 (2004).

29. Traub, L. M. Tickets to ride: selecting cargo for clathrin-regulated internalization. Nat Rev Mol Cell Biol 10, 583-596, https://doi. org/10.1038/nrm2751 (2009).

30. Taga, E. M. \& Van Etten, R. L. Human liver acid phosphatases: purification and properties of a low-molecular-weight isoenzyme. Arch Biochem Biophys 214, 505-515 (1982).

31. Kim, E. E. \& Wyckoff, H. W. Reaction mechanism of alkaline phosphatase based on crystal structures. Two-metal ion catalysis. J Mol Biol 218, 449-464 (1991).

32. Blesneac, I. et al. Phosphorylation of the Cav3.2 T-type calcium channel directly regulates its gating properties. Proc Natl Acad Sci USA 112, 13705-13710, https://doi.org/10.1073/pnas.1511740112 (2015).

33. Tsubaki, M. Fourier-transform infrared study of azide binding to the Fea3-CuB binuclear site of bovine heart cytochrome c oxidase: new evidence for a redox-linked conformational change at the binuclear site. Biochemistry 32, 174-182 (1993).

34. Kim, J. A. et al. Augmentation of Cav3.2 T-type calcium channel activity by cAMP-dependent protein kinase A. J Pharmacol Exp Ther 318, 230-237, https://doi.org/10.1124/jpet.106.101402 (2006).

35. Chemin, J. et al. Temperature-dependent modulation of CaV3 T-type calcium channels by protein kinases $\mathrm{C}$ and $\mathrm{A}$ in mammalian cells. J Biol Chem 282, 32710-32718, https://doi.org/10.1074/jbc.M702746200 (2007).

36. Hu, C., Depuy, S. D., Yao, J., McIntire, W. E. \& Barrett, P. Q. Protein kinase A activity controls the regulation of T-type CaV3.2 channels by Gbetagamma dimers. J Biol Chem 284, 7465-7473, https://doi.org/10.1074/jbc.M808049200 (2009).

37. Park, J. Y. et al. Activation of protein kinase $\mathrm{C}$ augments T-type $\mathrm{Ca}^{2+}$ channel activity without changing channel surface density. $J$ Physiol 577, 513-523, https://doi.org/10.1113/jphysiol.2006.117440 (2006).

38. Joksovic, P. M. et al. Mechanisms of inhibition of T-type calcium current in the reticular thalamic neurons by 1-octanol: implication of the protein kinase C pathway. Mol Pharmacol 77, 87-94, https://doi.org/10.1124/mol.109.059931 (2010).

39. Iftinca, M. et al. Regulation of T-type calcium channels by Rho-associated kinase. Nat Neurosci 10, 854-860, https://doi.org/10.1038/ nn1921 (2007) 
40. Hildebrand, M. E. et al. Selective inhibition of Cav3.3 T-type calcium channels by Galphaq/11-coupled muscarinic acetylcholine receptors. J Biol Chem 282, 21043-21055, https://doi.org/10.1074/jbc.M611809200 (2007).

41. Wolfe, J. T., Wang, H., Howard, J., Garrison, J. C. \& Barrett, P. Q. T-type calcium channel regulation by specific G-protein betagamma subunits. Nature 424, 209-213, https://doi.org/10.1038/nature01772 (2003).

42. Cueni, L. et al. T-type $\mathrm{Ca}^{2+}$ channels, SK2 channels and SERCAs gate sleep-related oscillations in thalamic dendrites. Nat Neurosci 11, 683-692, https://doi.org/10.1038/nn.2124 (2008).

43. Chiang, C. S. et al. The $\mathrm{Ca}(\mathrm{v}) 3.2 \mathrm{~T}$-type $\mathrm{Ca}(2+)$ channel is required for pressure overload-induced cardiac hypertrophy in mice. Circ Res 104, 522-530, https://doi.org/10.1161/CIRCRESAHA.108.184051 (2009).

44. Huang, C. H., Chen, Y. C. \& Chen, C. C. Physical interaction between calcineurin and Cav3.2 T-type $\mathrm{Ca}^{2+}$ channel modulates their functions. FEBS Lett 587, 1723-1730, https://doi.org/10.1016/j.febslet.2013.04.040 (2013).

45. Lin, S. S. et al. Cav3.2 T-type calcium channel is required for the NFAT-dependent Sox9 expression in tracheal cartilage. Proc Natl Acad Sci USA 111, E1990-1998, https://doi.org/10.1073/pnas.1323112111 (2014).

46. Comunanza, V., Carbone, E., Marcantoni, A., Sher, E. \& Ursu, D. Calcium-dependent inhibition of T-type calcium channels by TRPV1 activation in rat sensory neurons. Pflugers Arch 462, 709-722, https://doi.org/10.1007/s00424-011-1023-5 (2011).

47. Wolfe, J. T., Wang, H., Perez-Reyes, E. \& Barrett, P. Q. Stimulation of recombinant $\mathrm{Ca}(\mathrm{v}) 3.2$, T-type, $\mathrm{Ca}(2+)$ channel currents by CaMKIIgamma(C). J Physiol 538, 343-355 (2002).

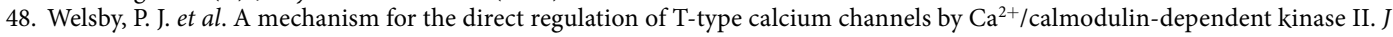
Neurosci 23, 10116-10121 (2003).

49. Yao, J. et al. Molecular basis for the modulation of native $\mathrm{T}$-type $\mathrm{Ca}^{2+}$ channels in vivo by $\mathrm{Ca}^{2+} /$ calmodulin-dependent protein kinase II. J Clin Invest 116, 2403-2412, https://doi.org/10.1172/JCI27918 (2006).

50. Suh, B. C. \& Hille, B. Recovery from muscarinic modulation of $M$ current channels requires phosphatidylinositol 4,5-bisphosphate synthesis. Neuron 35, 507-520 (2002).

51. Marty, A. \& Neher, E. Potassium channels in cultured bovine adrenal chromaffin cells. J Physiol 367, 117-141 (1985).

52. Roberts, W. M. Spatial calcium buffering in saccular hair cells. Nature 363, 74-76, https://doi.org/10.1038/363074a0 (1993).

53. Deisseroth, K., Bito, H. \& Tsien, R. W. Signaling from synapse to nucleus: postsynaptic CREB phosphorylation during multiple forms of hippocampal synaptic plasticity. Neuron 16, 89-101 (1996).

54. Klockner, U. et al. Comparison of the $\mathrm{Ca}^{2+}$ currents induced by expression of three cloned alpha1 subunits, alpha1G, alpha1H and alpha1I, of low-voltage-activated T-type $\mathrm{Ca}^{2+}$ channels. Eur J Neurosci 11, 4171-4178 (1999).

55. Kozlov, A. S. et al. Distinct kinetics of cloned T-type $\mathrm{Ca}^{2+}$ channels lead to differential $\mathrm{Ca}^{2+}$ entry and frequency-dependence during mock action potentials. Eur J Neurosci 11, 4149-4158 (1999).

56. Chemin, J. et al. Specific contribution of human T-type calcium channel isotypes (alpha(1G), alpha(1H) and alpha(1I)) to neuronal excitability. J Physiol 540, 3-14 (2002).

57. Leresche, N., Hering, J. \& Lambert, R. C. Paradoxical potentiation of neuronal T-type $\mathrm{Ca}^{2+}$ current by ATP at resting membrane potential. J Neurosci 24, 5592-5602, https://doi.org/10.1523/JNEUROSCI.1038-04.2004 (2004).

58. Monteil, A. et al. Molecular and functional properties of the human alpha $(1 \mathrm{G})$ subunit that forms T-type calcium channels. J Biol Chem 275, 6090-6100, https://doi.org/10.1074/jbc.275.9.6090 (2000).

59. Gomora, J. C., Murbartian, J., Arias, J. M., Lee, J. H. \& Perez-Reyes, E. Cloning and expression of the human T-type channel $\mathrm{Ca}(\mathrm{v}) 3.3$ : insights into prepulse facilitation. Biophys J 83, 229-241 (2002).

\section{Acknowledgements}

We are grateful to Drs R.C. Lambert, A. François and P.F. Mery for helpful discussions. We thank Dr. T. MooreMorris for critical reading of the manuscript. This work was support in part by the Centre National de la Recherche Scientifique (CNRS), by ANR-11-LABX-0015 (to PL) and by NIH grant GM102525 and March of Dimes Research Award 0529 (to SMT).

\section{Author contributions}

J.C., conceptualization, investigation, analysis, supervision, writing-original draft; T.T.S., M.C., J.L., I.B.; investigation, analysis; S.M.T., supervision, revised the manuscript; P.L., supervision, revised the manuscript.

\section{Competing interests}

The authors declare no competing interests.

\section{Additional information}

Supplementary information is available for this paper at https://doi.org/10.1038/s41598-019-52194-6.

Correspondence and requests for materials should be addressed to J.C.

Reprints and permissions information is available at www.nature.com/reprints.

Publisher's note Springer Nature remains neutral with regard to jurisdictional claims in published maps and institutional affiliations.

(c) (1) Open Access This article is licensed under a Creative Commons Attribution 4.0 International

License, which permits use, sharing, adaptation, distribution and reproduction in any medium or format, as long as you give appropriate credit to the original author(s) and the source, provide a link to the Creative Commons license, and indicate if changes were made. The images or other third party material in this article are included in the article's Creative Commons license, unless indicated otherwise in a credit line to the material. If material is not included in the article's Creative Commons license and your intended use is not permitted by statutory regulation or exceeds the permitted use, you will need to obtain permission directly from the copyright holder. To view a copy of this license, visit http://creativecommons.org/licenses/by/4.0/.

(c) The Author(s) 2019 